\title{
Prediction of individual response to anticancer therapy: historical and future perspectives
}

\author{
Florian T. Unger $\cdot$ Irene Witte $\cdot$ Kerstin A. David
}

Received: 6 January 2012/Revised: 23 October 2014/ Accepted: 27 October 2014/Published online: 12 November 2014

(C) The Author(s) 2014. This article is published with open access at Springerlink.com

\begin{abstract}
Since the introduction of chemotherapy for cancer treatment in the early 20th century considerable efforts have been made to maximize drug efficiency and at the same time minimize side effects. As there is a great interpatient variability in response to chemotherapy, the development of predictive biomarkers is an ambitious aim for the rapidly growing research area of personalized molecular medicine. The individual prediction of response will improve treatment and thus increase survival and life quality of patients. In the past, cell cultures were used as in vitro models to predict in vivo response to chemotherapy. Several in vitro chemosensitivity assays served as tools to measure miscellaneous endpoints such as DNA damage, apoptosis and cytotoxicity or growth inhibition. Twenty years ago, the development of high-throughput technologies, e.g. cDNA microarrays enabled a more detailed analysis of drug responses. Thousands of genes were screened and expression levels were correlated to drug responses. In addition, mutation analysis became more and more important for the prediction of therapeutic success. Today, as research enters the area of -omics technologies, identification of signaling pathways is a tool to understand molecular mechanism underlying drug
\end{abstract}

F. T. Unger $(\bowtie) \cdot$ K. A. David

Indivumed GmbH, Falkenried 88 Bldg. D, 20251 Hamburg, Germany

e-mail: unger@indivumed.com

K. A. David

e-mail: David@indivumed.com

I. Witte

Institute for Biology and Enviromental Sciences, Faculty V, University of Oldenburg, Oldenburg, Germany

e-mail: Irene.Witte@uni-oldenburg.de resistance. Combining new tissue models, e.g. 3D organoid cultures with modern technologies for biomarker discovery will offer new opportunities to identify new drug targets and in parallel predict individual responses to anticancer therapy. In this review, we present different currently used chemosensitivity assays including 2D and 3D cell culture models and several -omics approaches for the discovery of predictive biomarkers. Furthermore, we discuss the potential of these assays and biomarkers to predict the clinical outcome of individual patients and future perspectives.

Keywords Cell culture models .

Chemosensitivity assays · Genomics · Proteomics .

Personalized medicine $\cdot$ Response to therapy

\section{Introduction}

In the past decades, research in the field of molecular profiling of cancer was strongly affected by the rapid development of technologies. The complex disease-related alterations in the molecular networks, that are associated with response to chemotherapy, result in significant clinical heterogeneity among individual tumors and patients. A detailed and comprehensive understanding of drug response mechanisms is essential to ultimately guide a molecular based personalized anticancer therapy. Today, the complex networks of cellular mechanisms in cancer cells are just incipiently understood. Progress in all fields of cancer research, ranging from the optimization of cellular models and chemosensitivity assays over proteomics to genomics is revealing more and more facets of determinants of individual chemosensitivity. Besides studies in patients and xenograft models of tumors, 
Fig. 1 Schematic illustration of the concept of the realization of personalized medicine by molecular analysis



in vitro cell cultures are the most commonly used systems for the analysis of cellular responses to drug treatment. A whole spectrum of cellular models ranging from secondary cell lines and primary mixed cultures over multicellular spheroids to organoid cultures are being used in cancer research. These models are being constantly optimized to mimic the origin tumor and tumor microenvironment as close as possible. Cell culture models are the basis for the molecular analysis of individual drug response. Relatively common approach to measure cellular chemosensitivity is the use of various in vitro chemosensitivity assays, which basically only detect the sum of all specific cellular drug effects. This measurement of drug effects on cell viability is deeply integrated in basic research, as well as in the clinical setting for the general determination of chemoresistance of a patients" tumor. To investigate the molecular details of individual drug responses, genomic and proteomic methods were integrated in cancer research. These technologies enable comprehensive investigation of the multifactorial mechanisms underlying individual drug response by the simultaneous analysis of thousands of genes or proteins. This huge amount of generated data can be merged to a complex picture of molecular networks and will significantly contribute to the understanding of the diversity in individual drug response. The technical advances in all areas are enhancing the amount of information output rapidly and ultimately the interconnection of all fields of research should be able to combine molecular attributes to individual, molecular signatures of chemosensitivity. The molecular characterization of patients will shift the concept of anticancer therapy from standardized treatment of patients to specialized treatment concepts for molecular-defined subgroups of patients (Fig. 1). In the future, this individualization of anticancer therapy will increase survival and life quality of patients, by being able to provide maximal effective therapies and sparing them from uneffective therapies and side effects.

\section{Cellular models}

The prediction of response to chemotherapy at the molecular level is currently mostly based on data derived from in vitro experiments (Fig. 2). Besides studies in patient populations and xenograft models of tumors, cell cultures are the most commonly used in vitro systems for the analysis of cellular responses to drug treatment. Various types of cell culture models exist. These models differ in their ability to reflect the in vivo situation, which is of great importance for further translation of results to the clinical setting.

As a result of the gain in knowledge of cancer-specific signaling networks and metabolic pathways, it became obvious, that cell behavior is strongly influenced by the microenvironment of the cell $[1,2]$. These findings had great impact on the development of in vitro cell culture models and their use in drug discovery and translational research. 2D cell cultures are the oldest and widely used models in cancer research, comprising mainly clonal-secondary and infrequently primary cell lines. Clonalsecondary cell lines are inexpensive in acquisition and easy to handle. Due to their ability to grow infinitely, they are well applicable in high-throughput screenings, suitable for genetic modification and good sources for preparations of cell components (e.g. mitochondrial-, membrane-, nuclear fractions). However, the preparation of cell lines from a tumor, results in loss of the $3 \mathrm{D}$ in vivo structure and in diversity of cell populations, thus these models only partly represent the origin tumor. Alongside the progress in laboratory technologies, the design of more and more extensive in vitro models became possible. Based on first attempts to rebuild 3D tumor structures, using secondary cell lines and natural as well as artificial extracellular matrices (ECM's), the techniques for the preparation of such models rapidly advanced. Currently, the mixed culture of different cell types, the use of feeder layer cell lines and the induction of angiogenesis in these $3 \mathrm{D}$ cell culture 
Fig. 2 Exemplary illustration of different cellular models used in translational research



systems are main improvements in this area of research. Nonetheless, these models represent artificial microenvironments and many features of an original tumor cannot yet be displayed. Complex models such as in vitro 3Dorganoid cell cultures or xenografts currently best display the characteristics of an in vivo tumor. The cultivation of vital tumor tissue slices, for example, enables drug testing in a natural tumor environment and has the capability to reveal tissue composition dependent cellular responses to anticancer therapy. Xenografts also have the ability to mimic the in vivo microenvironment of a tumor in a physiological context, regarding nutrient supply, angiogenesis etc. However, using this model, differences in metabolism, body size and genetic background between the host species and humans have to be considered.

In summary, organoid cell cultures and xenografts represent valuable "bridge models" between in vitro cell lines and the clinical in vivo setting. The choice of a cell culture model for research should depend on the application in the study design and cost-benefit ratio.

Primary and secondary cell lines

Over 60 years ago, the first human clonal cancer cell line was established from a patient's tumors. Today, human tumor-derived clonal cell lines are able to grow in vitro, are easy to handle and thus they find wide application. Thousands of cell lines from diverse tumor entities can be purchased from different suppliers (e.g) [3, 4]. These cell lines are characterized and usually delivered including basic data, such as genetic profile (STR), morphology, doubling time, cytogenetics and references, by which additional data can be received using literature search. Being such robust and easy to handle models, secondary cell lines are a preferred starting point for the analysis of cellular mechanisms, e.g. resistance to anticancer therapy and signaling pathways. These models are also routinely used in versatile applications, e.g. testing of efficacy of compounds, examination of metastasis mechanisms, preparation of cellular compartments, extraction of proteins and DNA. Furthermore, secondary cell lines are well suited for artificial manipulation of cell characteristics, such as expression of mRNAs and proteins, mutations (knock-in) and modulation of chemosensitivity.

For example, approaches to understand acquired drug resistance are cancer cell lines with established drug resistance. Continuous exposure of these drug-sensitive cell lines to anticancer therapeutics in vitro, selects for the relatively rare drug-resistant clones, which are then further raised to a chemoresistant sub clone cell line. Comparative analysis of properties of the parental drug-sensitive cell lines and the selected drug-resistant cell lines has the potential to identify specific molecular mechanisms of drug resistance [5]. Hence, transformed cell lines and their parental counterparts are also commercially available and represent artificial, but defined models for the investigation of determinants of chemosensitivity.

Nowadays, secondary cell lines are integrated in huge compound screening programs for drug discovery and research programs to understand the underlying mechanism of individual response to chemotherapy. Secondary cell lines fulfill all requirements for implementation in highthroughput screenings, enabling the rapid screening of large panels of compounds. The National Cancer Institute 60 (NCI60) platform was the first high-throughput cancer cell line screening program and therefore triggered the development of adequate techniques. The experimental methods had to be adapted to the requirements of economic, high-throughput screenings, e.g. high-content data mining, automation of handling liquids, miniaturization of cell culturing and drug testing procedures. A major finding of the program was that compounds with similar patterns of cell line chemosensitivity tend to have common mechanism of action, which led to the development of new algorithms for data analysis and adaption of study designs. The NCI60 anticancer drug discovery program was 
reviewed in detail by Shoemaker [6], who highlighted its history and methodology. Learning from the NCI60 experiences, the Cancer Chemotherapy Center of the Japanese Foundation for Cancer Research (JFCR) established the JFCR-39 platform. This panel of 39 human tumor-derived cell lines included a subset of the NCI60 cell lines and additional gastric cancer cell lines [7]. A new algorithm for data analysis enabled the comparison of newly screened compounds with previously screened compounds to discriminate between new or previously described modes of action. Using the COMPARE algorithm and advanced data mining techniques, several new anticancer agents [8-11] were identified.

In drug discovery or predictive biomarker studies for the introduced 'targeted anticancer therapeutics', small panels of cancer cell lines cannot display the clinical activities of these compounds, which are often limited to small subgroups of molecular-defined patients. Taking this into account, high-throughput screenings are now being adapted to much larger panels of cell lines. To capture the genetic heterogeneity among diverse cancers, Mc Dermott and colleagues [12] developed an automated platform for the screening of the chemosensitivity of 500 solid cancer cell lines to kinase inhibitors. In this study, they observed the expected response rates with only small subgroups of cell lines showing responses to particular compounds. Therefore, a comprehensive cancer cell line platform was established, currently including 1,200 cancer cell lines. Due to the fact that only around $80 \%$ of those secondary cancer cell lines are adaptable to high-throughput screening, mostly caused by technical limitations such as insufficient doubling times or atypical culture requirements, this panel is referred to as the Center for molecular Therapeutics 1000 (CmT1000) [13]. This cell line panel is currently being used to investigate the genetic determinants for chemosensitivity. First results from this large data sets showed that tumor-derived cell lines recapitulate clinical findings concerning responses to targeted inhibitors [14].

Another, very recent approach in generating primary cell lines for in vitro experiments has been introduced by Lui et al. [15]. This approach initially comprised a method to indefinitely extend the life span of primary human keratinocytes using both fibroblast feeder cells and a Rhoassociated kinase (ROCK) inhibitor, and is also efficiently applicable to establish cell cultures from human and rodent tumors. This innovative technique provides significant opportunities for cellular diagnostics and molecular therapeutics (drug profiling), expands the value of biobanking and has the potential to greatly improve personalized medicine.

A general disadvantage of secondary cell lines is that they only represent one cell from a diverse tumor microenvironment which resembles the capabilities necessary for adapting to in vitro culture. It is still unclear in which manner adaption to in vitro culturing and multiple passaging influences cell characteristic/behavior. The establishment and cultivation of primary mixed single cell cultures always have been quite complicated [16]. Primary mixed cell cultures isolated from patient's tumors represent a wide spectrum of cell types abundant in vivo. This diverse mixture mainly consists of different epithelial- and mesenchymal cancer cells, tumor associated stroma and immune cells $[17,18]$. Therefore, these primary cell cultures more closely reflect the in vivo situation than secondary, clonal cell lines. However, several difficulties are still to overcome, while establishing primary mixed cultures. The basis for the preparation of primary, mixed cell cultures is vital tumor tissue and experience in cell culture handling. Besides the quality of tumor tissue, the method for preparation of single cells from a tumor, the surface preparation of cell culture dishes and finally the composition of the culture media are also essential parameters for a successful establishment of primary mixed cultures. The artificial shifts in and losses of cell populations, due to unnatural in vitro culturing and passaging, limits the maximal diversity of cell types to low passage primary, mixed cultures. Most studies using primary cells prepare cell cultures shortly after tumor resection and disseminate cells directly for experiments. Studies regarding the in vitro chemosensitivity of primary cells were conducted in different tumor entities e.g. small cell lung cancer [19], colorectal cancer [20, 21], gastric cancer [22], Leukemia [23, 24], ovarian cancer [25-27] and head and neck cancer [28, 29]. One limiting factor is that, the diversity of cell types will decrease during in vitro cultivation, due to the dissimilar ability of different cell types to proliferate in vitro and survive passaging. Another issue limiting the predictive value of these cell cultures is the loss of the $3 \mathrm{D}$ architecture of the origin tumor. Although the in vitro analysis of cultured cell lines is associated with artifacts related to effects attributed to a non-physiological environment and long-term passage in culture, it was shown that cancer cell lines retain most of the genomic features of the primary tumor [30, 31]. This has not yet been shown for proteomic features of cancer cell lines. The awareness of the importance of the tumor microenvironment and the three-dimensional aspects of solid tumors, in the response to anticancer therapy has initiated efforts to display these features in vitro more accurately [32-34].

There are also several other important factors to take in regard to mimic the in vivo microenvironment of a tumor in vitro. For example, a whole field within cancer research is dedicated to the investigation of hypoxia, which is defined as inadequate oxygen supply to cells and tissues, in solid tumors and implications on anticancer treatment [3540]. The oxygen concentration of $21 \%$, used in most 
in vitro culture systems is not physiological in regard to the limited oxygen supply of cells within a solid tumor.

\section{Multicellular spheroids}

Since it has been shown that the cellular signaling network, e.g. regulation of apoptosis is influenced by $3 \mathrm{D}$ cell organization and multicellular complexity, new cell culture models for a more realistic investigation of tumor cell behavior ex vivo are urgently needed [41]. To establish such models, it is necessary to maintain or reconstitute an environment which closely resembles the tumor in vivo. One of the first approaches of rebuilding the 3D microenvironment during in vitro cultivation and drug testing was the development of a culture model called "Spheroids". In 1970, the first spheroid model was devised by Sutherland [42]. Meanwhile, spheroids have been grown from a variety of normal and tumor cell lines and used in different assays, to study anticancer therapy efficiency as well as 3D cellular interactions $[43,44]$. Single cell cultures were used to establish an organoid-like 3D model using different techniques [45, 46]. These different culture techniques include various artificial as well as natural ECM's [47, 48] and mechanical methods to generate defined, roundly shaped cell clusters. Matrices, such as agarose, collagen, gelatin or matrigel allow the establishment of culture systems with well-defined geometry, wherein the 3D structure affects interactions between cells. This usage of 3D matrices has been reported to show fruitful results in recapitulating tissue functions in $3 \mathrm{D}$ [49, 50]. Besides various cancer cell lines, cell types like Madin-Darby canine kidney cells and fibroblasts, have also been monitored in $3 \mathrm{D}$ contexts and have provided valuable insight into the basic molecular mechanisms of polarity, adhesion, cell migration and response to anticancer therapy [51-53]. Numerous studies have documented differences in cancer drug sensitivity between cells cultured in monolayers and those grown in 3D cultures [54-56]. Previous studies have shown that certain drugs are more effective in 3D cell culture systems [57-60], although other drugs showed greater activity in the 2D cell culture systems [61, 62]. These days, fewer than 100 human tumor cell lines have been reported to grow in spheroid cultures [63]. Platforms based on tumor spheroids have been developed and are being used for analysis of individual chemosensitivity and secondary screening of potential new anticancer compounds $[64,65]$. The application of spheroids in drug screenings has been reviewed by Friedrich and colleagues [66]. However, it remains to be demonstrated comprehensively that chemosensitivity data derived from 3D cell cultures captures clinically relevant responses more precisely than standard 2D cultures. Furthermore, these systems cannot completely mimic the complex tissue architecture and the high degree of variability seen in individual tumors.

Organoid cultures

It has been shown that signaling and metabolic pathways in cell lines have distinctly different expression patterns compared to tumor tissues. Pathways in cell lines tended to be upregulated compared to tumor tissue with exceptions in genes involved cell adhesion, ECM-receptor interaction and focal adhesion [34, 67]. As discussed before, spheroids are a good approximation to the in vivo tumor, but still lack the natural tumor environment, including the state of receptors and corresponding extracellular signaling between diverse cell types naturally being present in the tumor. Therefore, the development of in vitro organoid cell culture models was an essential step for translational research. First experiments were performed in 1967 by Matoska and Stricker, using tumor cubes of approximately $1 \mathrm{~mm}^{3}$ [68] for in vitro culturing. Later, an in vitro histoculture system, using a native-state collagen-sponge gel to support the three-dimensional growth of tumor tissue sections was developed, called the Histoculture DrugResponse Assay (HDRA) [69]. Features of the histoculture system include the maintenance of three-dimensional tissue architecture and the use of histological autoradiography or colorimetric assays as endpoints for determination of chemosensitivity [70, 71]. Ohie et al. [72] published a protocol on the Method of the HDRA. The reliability and utility of the HDRA were examined in several clinical studies for different tumor entities, e.g. oral squamous cell carcinoma [73], head and neck cancer [74], gastric cancer [75], colorectal cancer [76] and ovarian cancer [77]. Up to now, it has not been shown that the HDRA is also able to predict efficiency of targeted drugs such as small molecules and antibodies.

The past years have seen unprecedented developments in the use of human tissue surrogates in vitro. Clevers et al. [78] developed a technique in which adult stem cells, originating from fresh tumor tissues, are embedded in a three-dimensional matrix and allowed to self-organize into epithelia of the respective organ of origin. The resulting organoids represent the physiology of native epithelia much better than traditional cell lines. Mini-guts, for example, reproduce the epithelial architecture of small intestine and colon [79, 80]. If combined with genetic information and pharmacological profiles, such an organoids could aid in identifying markers that predict a patient's drug response similar to the Cancer Cell Line Encyclopedia [81].

Parallel to the development of tissue microtomes enabling the preparation of thin slices of fresh tissue, precision cut cancer tissue slices from tumor tissue have 
become more popular as ex vivo systems. It has been shown, that cell viability of tissue slices was maintained in in vitro culture for at least 4 days [82]. After treatment with different compounds (chemotherapeutics, small molecules, antibodies), slices can be fixed by immediate freezing or by formalin. Frozen slices can be used for several assays, e.g., functional drug effects on viability (ATP), apoptosis (activation of caspase 3/7), proliferation (BrdU) and signal pathway analysis (activation of phosphoproteins). Formalin-fixed slices can be utilized for immunohistochemical analysis of target expression, drug effects and cell-cell interactions. Furthermore, laser capture micro dissection can be applied, allowing the separation of different cellular compartments, for molecular analysis of pure cell populations. Viara and colleagues reported on a preclinical model of organotypic culture for pharmacodynamic profiling of human tumors [83]. This model demonstrates the ability to detect pharmacological interventions ex vivo in a presevered original cancer microenvironment. Due to the broad spectrum of molecular techniques that can be implemented, organoid cell culture models offer a unique opportunity to understand the complex basis of cellular responses to anticancer therapeutics of all groups, e.g. classical chemotherapeutics, small molecules and therapeutic antibodies [84]. Despite the advantages of the models, difficulties in obtaining specimen and limited viability of these tissues in culture over time represent major obstacles. The successful cultivation of tissue slices is also dependent on tumor entity, highly adapted culture conditions in terms of media supplements and other culture techniques. In the future, the use of miniaturized cell-based models that are specifically engineered to closely reflect in vivo behavior can reduce costs and add efficiencies to drug development, but most importantly increase the accuracy of molecular prediction of response to anticancer therapy.

\section{Xenografts}

Currently existing in vitro cancer cell culture models, such as primary cell lines and organoid cultures are a solid basis for molecular drug testing, but they do not reflect the natural tumor environment in all facets. The final application of anticancer drugs takes place in the in vivo situation, in the patients. Since it is unethical to use patients for preclinical research, xenograft cancer cell culture models were developed to facilitate drug testing in vivo and thus improve basic and translational research and prediction of individual response to chemotherapy. Cancer cell characteristics, such as chemosensitivity to anticancer chemotherapy, are strongly affected by several parameters in a physiological, in vivo, situation. In contrast to in vitro cell culture models, xenograft models offer micro environmental conditions, e.g. tumor architecture, angiogenesis, metastasis close to the real patient. The injection of vital human cancer cells or even transplantation of human tumor fragments is therefore still essential to study cancer in an in vivo situation [85, 86]. Among the existing in vivo cell culture models, the mouse model is widely used. It bears the relative advantages of good availability, low space requirements, low cost, ease of handling and fast reproduction rate. Mouse xenograft models are extensively being used to study individual response to anticancer therapy and drug development [87, 88]. Several studies on DNA and protein level were conducted in mice xenografts to understand and predict response to anticancer therapy. For example, gene expression signatures and plasma protein biomarker have been reported to predict efficiency of therapy ex vivo [89-91].

But there are also multifaceted parameters affecting outcome when conducting xenograft experiments, e.g. site of implantation, growth properties and size of tumor at the time treatment is administered, agent formulation, scheduling, dose and the selected endpoint for assessing activity. A basic review on the mouse model in drug testing was published by Mattern L. and colleagues in 1988 [92]. The application of xenografts in drug testing has been reviewed elsewhere in detail [93, 94]. Despite the relatively comprehensive ability of mice models to mimic the clinical situation in patients, there are differences between mice and humans which might have an impact on the predictive value of this model [95]. Mice and humans obviously differ largely in body size and lifespan. Although mice have a similar incidence of cancer at the end of the life cycle, they primarily develop cancers in mesenchymal tissues, e.g. lymphomas and sarcomas. Most cancers in humans are of epithelial-origin and lead to carcinomas. Furthermore, the basal metabolic rate of mice is much higher, which results in increased generation of reactive oxygen species, other mutagens and also distinct metabolism of anticancer drugs in mice from humans.

Xenografts may also fail to recapitulate immunological aspects of tumor-stroma interactions that are present in human patients. Cell signaling interactions between cancer cells and host stromal cells may not occur properly due to interspecies incompatibilities, e.g. interactions of ligands of one species with receptors of the other [96, 99]. Those incompatibilities may impact various characteristics of tumors, e.g. drug response and metastatic behavior. [97, 100]. A short overview of the challenges of selecting the 'right' in vivo oncology pharmacology model and improving the translation of these models to a clinical setting was summarized by Firestone B, 2010 [98, 101].

Nonetheless, xenograft model are useful preclinical models. The better these models are characterized on genome and proteome level and by implementing the 
Fig. 3 Exemplary illustration of different chemosensitivity assays used in translational research

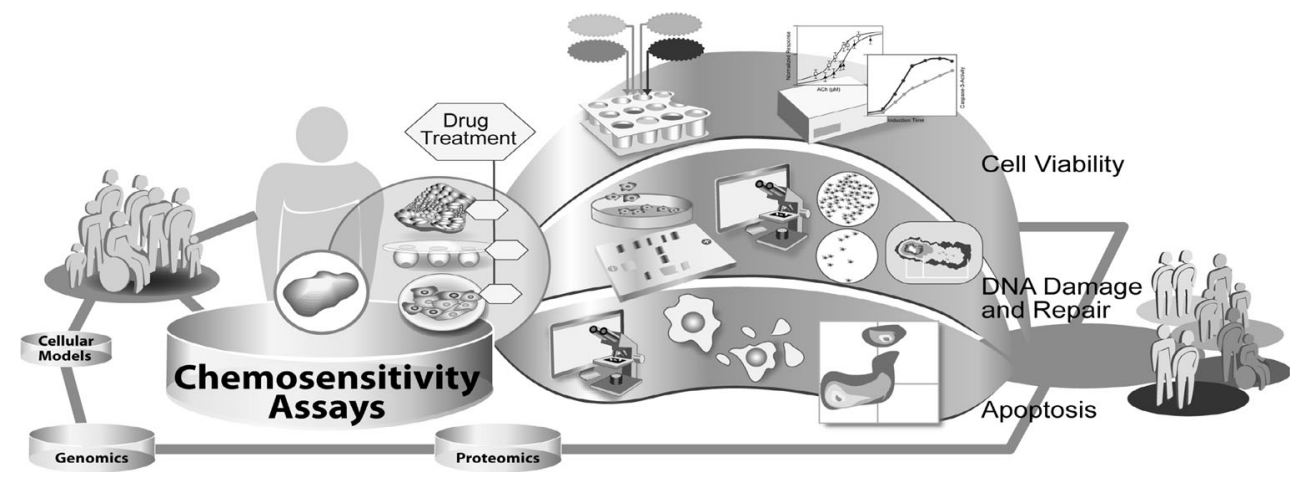

learning experience while using these models, the more basic information on the individual response to anticancer therapy will be gained.

\section{Chemosensitivity assays}

First experiments to determine the individual chemosensitivity of tumor cells from cancer patients were made in the mid-1950's [102]. At that time, techniques for chemosensitivity testing were developed on the basis of well-known parameters such as colony forming ability, growth inhibition or cell viability. In theory the overall effects of cytotoxicity are the sum of all specific cellular effects underlying multi-factorial mechanisms. Therefore, in vitro chemosensitivity testing can potentially predict response to anticancer therapy either by determination of the death of all cancer cells or at least by complete growth inhibition. Currently, chemosensitivity tests find wide application in basic and translational research (Fig. 3). The measurement of drug effects on cell viability is integrated in basic research, for the detailed analysis of efficiency and mode of action of drug candidates, as well as in the clinical setting for the general determination of chemoresistance of a patient's tumor. Firstly, the measurement of cancer cell chemosensitivity to miscellaneous compounds with potential anticancer activity is the basis of most drug discovery programs. Previous publications described various phases of the development of an in vitro anticancer drug screen, aimed at the identification of compounds showing selective growth inhibition or cytotoxicity towards particular cell or tumor types [102, 103]. These screening programs require very robust, automated chemosensitivity assays for the measurement of drug effects on cancer cell viability or growth. Therefore, many studies were performed comparing chemosensitivity assays in regard to their sensitivity, reproducibility, applicability to cancer cell lines of various origins and potential for adaption to high-throughput [24, 104-106]. Secondly, in vitro chemosensitivity tests are, to some extent, applied in the clinical setting to determine chemoresistance in a patients" tumor. This may help to guide individualized anticancer therapy, especially in secondline treatment where the guidelines for therapy are not always clearly defined [107].

In vitro chemosensitivity tests are not approved for predicting or guiding therapeutic treatment of patients in first-line therapy or routine use.

Implementation of cell viability assays in preclinical drug testing

Besides a whole spectrum of assays, measuring events indicating cell viability, the most often used cell viability tests today in chemosensitivity testing are the MTT assay [108], the FMC assay [109], the ATP-TCA [26, 110] and SRB assay [102]. The four different assays measure cytotoxicity as a decrease of fundamental metabolic activity (MTT assay, FMC assay) or by the reduction of essential biomolecules (ATP assay) and cell mass (SRB assay). The MTT tetrazolium salt colorimetric assay is based on the metabolic reduction of 3-(4, 5-dimethylthiazol-2-yl)-2, 5-diphenyltetrazolium bromide (MTT). The yellow tetrazolium salt MTT is converted by mitochondrial dehydrogenases of metabolically active cells to an insoluble purple formazan product. The optical density can be detected by precise spectrophotometric measurement using a plate reader [111]. The fluorometric microculture cytotoxicity assay (FMCA) measures fluorescence generated from cellular hydrolysis of fluorescein diacetate (FDA) to fluorescein by cytosolic esterase activity. The measured enzyme activity in combination with indirect detection of cell membrane damage is determined as parameters for cell viability [112]. In the ATP-tumor chemosensitivity assay (ATP assay) the intracellular ATP content is quantified by measuring luminescence produced by a reaction of ATP with luciferase and D-luciferin [113]. The assay allows for a rapid, sensitive measurement of cellular ATP content. ATP levels are linearly related to the number of viable cells and increased with time in cell line cultures correlating 
with growth kinetics [114]. The sulforhodamine B (SRB assay) measures whole protein content for the detection of viable cells. SRB is a pink aminoxanthene dye with two sulfonic groups that bind to basic amino-acid residues under mild acidic conditions. The binding of SRB is stoichiometric, the amount of dye extracted from stained cells is directly proportional to cell mass [27]. Using this assay to determine cell growth or viability, one assumes that dead cells either lyze, are removed during the procedure or otherwise do not contribute to the colorimetric end point. After fixation and staining procedures, tested cells can be stored indefinitely, which also contributes to highthroughput applicability. [115, 116]. The quantitative results of these different chemosensitivity tests are similar, although sensitivity varies. The lowest sensitivity was found for the MTT assay. Here, a great number of cells $(25,000$ cells/well $)$ are needed to get reliable results. The MTT assay is therefore not applicable when the tumor biopsy is small. For the SRB assay [117] and the FMC assay [27] around 2,000 cells/well are sufficient. The ATP assay is reported to be able to detect down to ten cells/well. In the past chemosensitivity assays have been technically optimized continuously. Several new data analysis methods were established, but the best comparison with the clinical outcome has yet been achieved by the "sensitivity index" (SI) rather than the determination of the IC50 values or the AUC index [118]. Currently, chemosensitivity is a basic parameter for anticancer drug efficiency and in combination with several other read outs of drug effects integrated in several drug discovery and preclinical drug testing platforms.

For the initial large-scale drug screening program, called the in vitro anticancer drug discovery project of the National Cancer Institute (NCI), the sulforhodamine B (SRB) assay has been chosen, because of its high level of sensitivity, adaptability to high-throughput screening and endpoint stability $[115,116]$. This project tested 10,000 or more samples per year in a manner that requires robust technology for the analysis of several million individual measuring points [119]. The SRB assay has mostly been used for the measurement of cytotoxicity and cell growth in high-throughput screening and basic research. Thus, in vitro chemosensitivity data from this assay has rarely been correlated to clinical outcome. By contrast, the chemosensitivity data from cancer cells measured with the MTT, FMC and ATP assays have been correlated with the efficiency of anticancer therapy in a clinical setting. Thereby, the ATP assay was preferably applied. Even though not all cancer types can be examined because of the above described limitations, correlations of the in vitro data with clinical outcome were obtained for ovarian carcinomas [118], breast carcinomas [119], leukemia [120], melanomas [107], colorectal carcinomas [121], lung carcinomas [122] and gastric cancer [123]. Most results exist for ovarian and breast carcinomas.

Besides monotherapies, two or more anticancer drugs are often used in the in vivo clinical setting, sometimes applied simultaneously in other cases sequentially, with intermissions of one or more weeks. This situation can hardly be mimicked by in vitro assays. Without the knowledge of the pharmacokinetics of the single therapeutics applied in combination, the ratio of the substances in the cells is unknown. Strong concentration-dependent combination effects between different anticancer drugs were observed [124, 125]. Synergistic, as well as antagonistic effects were found depending on the sequence of drug treatment for the combination of paclitaxel and cisplatinum $[125,126]$ and for combinations of platinum compounds with paclitaxel and colchicines [127]. Besides these limitations another point of concern is the drug treatment time in vitro. During a short one-day incubation time growth inhibition or colony forming ability cannot be measured. An incubation time which allows the cells to duplicate, at least 2 days to several weeks, is necessary for the measurement of colony forming ability or growth inhibition. Therefore the duplication time of the cancer cells limits these methods. Furthermore, isolated primary cancer cell cultures are difficult to cultivate in vitro. The rate for successful cultivation and passaging of primary cell cultures is low. Stromal cells, such as fibroblasts which cannot be totally separated during isolation generally grow faster than the cancer cells, which may lead to false results. Serum free medium is reported to selectively reduce the growth of fibroblasts [128]. Soft agar used in clonogenic assays is also reported to hinder fibroblasts from forming colonies [129]. However, it is not known how these adapted cell culture conditions influence the growth and characteristics of cancer cells. Especially in cancer types where stromal cells influence cancer cell growth, e.g. squamous cell carcinomas the in vitro data may not reflect the in vivo situation.

The low response following physician choice especially in the second or third line therapy, with little if any benefit for the patients, demands in vitro chemosensitivity testing which leads to higher response rates as published previously [128]. In addition, for the determination of drug resistances these assays have shown convincing results [27, 130], which recommend the in vitro drug resistance measurement routinely at least in the second-line therapy. In the first-line therapy where the oncologist can choose between several chemotherapies with equivalently efficacious response rates, a chemosensitivity assay directed treatment could also be of advantage [128]. Several studies reported weak to good correlations of in vitro to in vivo data. Nonetheless, further studies were recommended for clinical validation by most authors. The American Society 
of Clinical Oncology (ASCO) furthermore recommended comparing patients, whose individual therapy resulted from chemosensitivity testing with patients, whose therapy was chosen empirically [131]. They did not recommend in vitro chemosensitivity testing for chemotherapy guidance outside of clinical trials. Others contradicted the ASCO especially because of the low number of studies considered in their review article leading to insufficient conclusions [132, 133].

In summary, chemosensititvity testing is deeply integrated in basic drug testing and preclinical research. Various methods are used to determine the sum of various specific and unspecific drug effects on cells as decrease in viability or cell death. The application of individualized anticancer therapy based on in vitro chemosensitivity testing in the clinical setting has been conducted using several different laboratory methods [96, 134]. Correlations of in vitro results with clinical outcome have indicated predictive accuracies of 57-83\% for drug sensitivity and $>90 \%$ for drug resistance [135-139]. Although studies have demonstrated the predictive value of different chemosensitivity assays, the insufficient number of prospective randomized studies validating efficiency and benefit has yet limited the routine application in the clinical setting.

\section{DNA damage and repair}

Other multi-factorial endpoints such as DNA damage [140] and DNA repair [141] were examined as parameters for determining cancer cell chemosensitivity, as well. A broad spectrum of anticancer drugs induces DNA damage which, in turn, leads to cell death. Quantitative DNA damages could therefore correlate with the clinical outcome of patients treated with DNA damaging chemotherapeutics. The comet assay, a method for the measurement of DNA damage [140, 142] is used in chemosensitivity testing because it is a quick, sensitive method that does not require cell division. Also, only very few cells are needed, so that cell numbers obtained by needle biopsies are in general sufficient. Unger et al. [143] measured DNA damage induced by cis- and carboplatin, doxorubicin and gemcitabin in primary cells of ovarian carcinomas. In parallel, they measured the cell chemosensitivity and correlated both parameters. Like others, they found a strong correlation for the platinum compounds [144] but not for doxorubicin and gemcitabin. Multiple targets of these cytostatics may explain these results. For platinum compounds the main cause of cytotoxicity is thought to be the induced DNA damage [145]. In the future the comet assay could become important in testing for platinum resistances in patients especially in the second-line and third-line therapies.
DNA damage is coupled with DNA repair, which has been reported to be heterogeneous among individuals [146]. For example, the determination of an individual degree of induced DNA damage and repair capacity using the comet assay [147] is therefore thought to be a prognostic factor for chemosensitivity. Furthermore, DNA damage response pathways have been shown in experimental models to be associated with resistance or sensitivity to DNA damaging agents. Teodoridis et al. [148] examined potential associations of methylation patterns of DNA damage response genes with response to anticancer therapy. Over the last decade, there has been a tremendous increase in the understanding of the mechanisms of DNA damage detection, signaling, and repair, and these findings have suggested therapeutic opportunities for anticancer drugs that modulate these pathways [149, 150]. For example, there is a large body of experimental evidence showing that DNA damage checkpoint kinase inhibitors can enhance the efficiency of both conventional chemotherapy and radiotherapy, and several agents have entered clinical trials [151]. In the presence of DNA lesions, cell cycle checkpoints and repair mechanisms are being activated and a prominent route of cell elimination is apoptosis [152]. Specific DNA lesions induced by DNA damaging anticancer drugs that trigger apoptosis have been identified. These include O6-methylguanine, base N-alkylations, bulky DNA adducts, DNA cross-links and DNA double-strand breaks (DSBs). DNA damage induced cell death by apoptosis has been reviewed by Roos et al. [153].

\section{Apoptosis}

In 1972, Kerr, Wyllie and Horvitz described the phenomenon of programed cell death and initially called this process of natural cell death apoptosis. Since then, apoptosis has developed into an area of intense scientific interest which encompasses the study of mechanisms involved in mediating the cell biology of programed cell death. Two major cell-intrinsic pathways for inducing apoptosis have been identified. One begins with ligation of cell death receptors, and the other involves mitochondrial release for cytochrome c. Both pathways result in characteristic morphological changes in nearly all cell types such as membrane blebbing cell shrinkage, nuclear fragmentation, chromatin condensation and chromosomal DNA fragmentation. Many of the changes reflect the selective proteolytic cleavage of various intracellular polypeptides (e.g., lamins, caspases). Based on these alterations many different in vitro methods have been devised to detect apoptosis. Examples are the TUNEL (TdT-mediated dUTP Nick-End Labeling) analysis [154], the DNA laddering analysis for the detection of fragmentation of DNA in populations of cells or in individual cells [155], the Annexin-V analysis 
that measures alterations in plasma membranes [156, 157], and the activation of caspases (family of cysteine proteases) [158]. In addition, apoptosis related proteins such as p53, Fas, Bcl-2 and Bax are commonly analyzed to understand details of the complex picture of the apoptotic pathways.

Previous studies have demonstrated that a wide range of anticancer agents, including chemotherapeutic agents, hormones, and various biologicals, induce apoptosis in malignant cells in vitro. Since apoptosis is a regulated process, biochemical alterations that make cells more or less susceptible to apoptosis might affect their sensitivity. It has been proposed that tumor chemosensitivity to anticancer drugs may partly be attributable to the degree of activation of a genetic program for cell death. One of the current models suggests that many different anticancer drugs such as doxorubicin, etoposide, and cisplatin trigger apoptosis by inducing the synthesis of FasL, which ligates Fas and activates caspase-8. However, other studies have revealed many exceptions to this model and propose that the majority of anticancer drugs initiate apoptosis by the cytochrome c/Apaf-1/caspase- 9 pathway resulting in mitochondrial membrane permeabilization (MMP). Since mitochondrial permeabilization is a relatively early event in the apoptosis, detecting this event might be more useful in revealing the presence of apoptotic cells than other assays, such as those that measure caspase-3 activation or DNA fragmentation. In vivo studies of induction of apoptosis in experimental models and patients undergoing therapy have yet been limited to histological examination, thus providing a static picture of apoptosis, rather than an observation of ongoing cell death. However, in vivo detection of apoptosis is also hampered by the rapid clearance of apoptotic cells by phagocytes [159]. Preclinical studies on tumor cells analyzing the contribution of caspases to anticancer therapy resistance have to our knowledge not yet been published. However, inhibition or loss of caspase expression has been proposed to confer resistance to different anticancer drugs $[160,161]$. The potential impact of caspases and their activators on resistance is also supported by 'knock-out' mouse models with distinct variations of the Apaf1, caspase-3 or caspase-9 gene, which are resistant to various apoptotic stimuli in different tissues [162-164].

Finally, alterations in the p53 gene and implications in the induction of apoptosis represent one of the most studied genetic events in cancer cells and are suggested to be linked to chemosensitivity. Nevertheless contradicting results were reported. For example, significant correlations of overexpression of p53 and prognosis were published [165] for squamous cell carcinomas, but no correlations were found in another study [166].
Detailed analysis of the induction of apoptosis is nowadays mainly integrated in comprehensive drug testing platforms for preclinical testing of anticancer drug candidates. Therein, the in vitro analysis of the mode of action and efficiency of a drug candidate is the main focus.

\section{Genomics}

Cancers arise from a multistage process in which tumor cells progressively acquire a sequential accumulation of genetic alterations. The genomic changes occurring in the transformation of normal cells to cancer cells influence several genetic mechanisms. These events destabilize the normal cellular homeostasis e.g. gains, losses or translocations of large regions of chromosomes, single-nucleotide substitutions, copy number changes and methylation events. Among these alterations, intragenic mutations play an important role in activating oncogenes or inactivating tumor suppressor genes. This results in misregulation of cellular signaling, e.g. proliferation and apoptosis and thus generates a survival advantage for the cancer cell [167, 168]. Certain mutations may be associated with specific types of cancers or may be common to several types of cancers. Currently, most of our knowledge of these alterations stems from studies of single genes in specific cancers. A variety of high-throughput techniques has now been developed for profiling and analysis of cellular networks, providing means to survey the cancer genome and transcriptome. By the complete sequencing of the human genome and progress in bioinformatical research, the understanding of cancer-related genomic alterations and expression patterns has grown. Nonetheless, understanding of the complex basic patterns and functions of molecular alterations on the genomic level are a great challenge. Therefore, the main focus of oncogenomic profiling lies on the analysis of DNA repair, mutation status, gene expression, gene copy number and genome stability (Fig. 4). Based on the current knowledge of the oncogenomic alterations existing in cancer genotypes, key mutations of cancer development [169], new subclasses of cancer types have been identified [170, 171] and even models for the prediction of clinical outcome have been calculated [172, 173].

The prediction of response to therapy is a relatively new field of oncogenomics. The strong heterogeneity of individual tumors in terms of clinically observed drug response is an important reason for the need for individualized, molecular guided therapy, but also for the difficulties in realizing this goal. There is accumulating evidence that drug-specific response pathways are influenced by the individual genotype and gene expression, which led to efforts to identify gene signatures and gene mutations 
Fig. 4 Exemplary illustration of different genomic approaches used in translational research

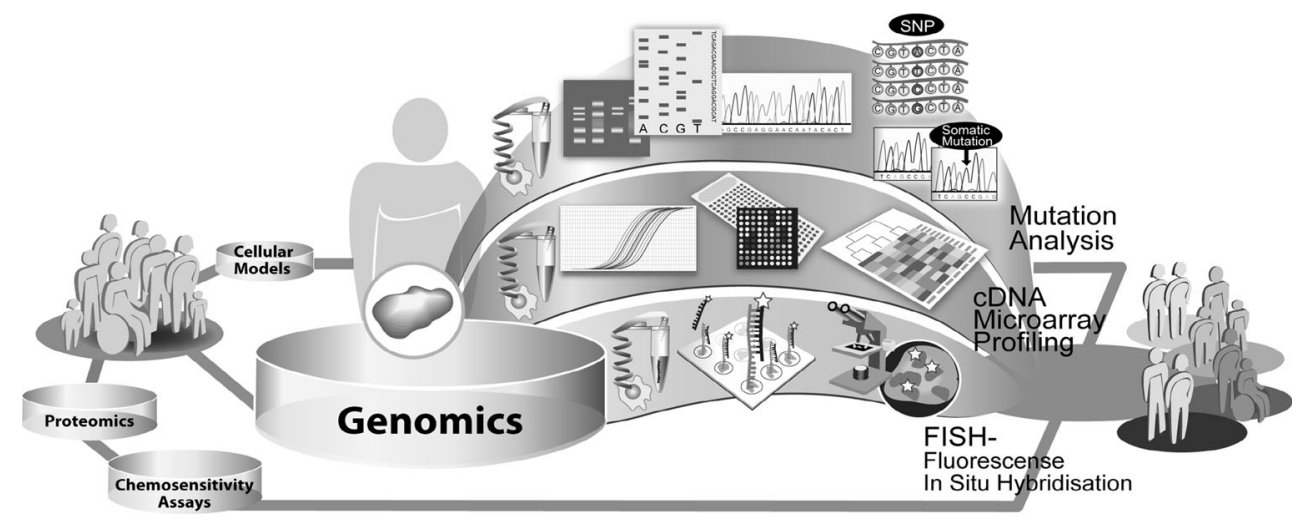

predictive for chemosensitivity. This will ultimately lead to the development of strategies for patient-tailored anticancer therapy which are based on the individual molecular profile of a tumor [172].

\section{Mutation analysis}

During the past decades, there have been great advances in experimental methods for genome characterization built on 'first-generation' capillary-based DNA sequencing, also known as Sanger sequencing [173]. These sequencing methods can be crudely divided into a general and a targeted approach. The products of both approaches are amplified templates, either by multiplication in plasmids or as PCR amplicons. Sequence determination is then performed by high-resolution electrophoretic separation in a capillary-based polymer gel. Bioinformatical software converts these signals into DNA sequences and calculates error probabilities for each base-call. Approaches, like the second-generation parallel sequencing techniques increased the throughput and decreased the cost of nucleotide resolution. Second-generation sequencing technologies are based on the simultaneous detection of nucleotides in arrayed amplified DNA products originating from single DNA molecules [174]. Advanced technologies like next-generation sequencing approaches are currently at the front of research with great potentials to give new insights in tumor heterogeneity and individual drug responses. High-throughput sequencing technologies including those created by Illumina (Illumina, Inc.), 454 (Roche Diagnostics Corp.) and SOLiD (Life Technologies), enable whole genome sequencing at an unprecedented scale and dramatically reduced costs over the gel capillary technology used in the human genome project.

Advanced next-generation sequencing systems are capable of sequencing a human genome at $30 \times$ coverage in less than 1 week. These next-generation sequencing (NGS) systems use parallel sequencing to generate hundreds of millions of short (36- to 150-bp) DNA reads that can be aligned to the human genome. Although a number of different NGS strategies have been developed, the paired-end strategy from Illumina Inc. has become the tool of choice for most cancer genome studies published to date. While most cancer genome studies so far have focused on single patients, this pattern is changing as a result of ongoing international collaborations and decreases in the cost of sequencing. The hope is that NGS data will shorten the road to personalized medicine, in which treatments and therapies are tailored to target the unique features of individual tumors and tumor subpopulations [175] based on mutations that define sensitivity and drug resistance (http://www.cancerrxgene.org/).

The extensive genotyping of individual tumors displayed thousands of mutations in an individual cancer genome [176]. The extent of genetic variation in the genomes of the human population is far greater than had been estimated [177]. While the impact of the vast majority of these mutations currently remains unknown, basic and translational research has pointed out, that a much smaller group of mutations is not only necessary for the development of cancer but is also required for the maintenance of the tumorś survival [178]. The presence of such 'driver' mutations sustains tumors and can simultaneously represent a cancer-specific target for therapy [179-182]. For example, the mutations of the tumor suppressor genes TP53 and EGFR are among of the most studied mutations in cancer research with implications in tumor development, progression and response to chemotherapy [183]. Several mutations in genes, encoding for proteins involved in cell signaling pathways, have a strong impact on the field of targeted therapy. This area of cancer research is reviewed elsewhere in detail [180, 184-190].

Individual alterations and differences in metabolism, inand efflux of xenobiotics and cellular signaling pathways caused by mutations are some of the reasons for the diversity in individual response to conventional chemotherapy [191]. The most common form of mutation in the 
human genome is the single-nucleotide polymorphism (SNP). Functional genomic polymorphisms in drug target genes [193], metabolising enzymes [194] and DNA-repair enzymes [195] may have important implications for drug efficiency. Therefore, these sequence alterations are determinants of variations in metabolism of drugs and associated side effects, because they have an important influence on the expression levels and activities of the corresponding proteins [196]. A recent study found that anticancer drug susceptibility-associated SNPs were associated with the transcriptional expression level of genes as potential master regulators [197]. A significant body of evidence supports the concept of predicting drug efficiency and side toxicity by SNP genotyping. For example, transcriptional contributions of genetic polymorphisms to cytotoxicity of cisplatin using human cell lines were listed [198]. Furthermore, in 2010 a genome-wide identification of chemo-sensitive SNP markers in colorectal cancer was conducted by Kim and colleagues [199]. Besides the characterization of the NCI60 panel regarding the mutation status of 24 genes, causally implicated in oncogenesis and drug response [200], the panel was also screened for chemosensitivity associated SNPs. This resulted in several studies dealing with the establishment of pharmacogenetic markers [201, 202].The impact of polymorphisms in genes involved in anticancer drug efficiency, response to chemotherapy and potential side effects has been reviewed elsewhere [203, 204]. Whereas the current knowledge about SNPs provides us with invaluable tools to find and understand significant associations between SNPs and drug response, we do not fully understand the genetic complexity of the attributes, underlying individual variability in drug response. Interpretations of associated studies are complicated by the number of genes, variants in each gene and the frequency of a variant within a population. The location of a variant SNP in the coding region, the regulatory region, or the non-coding region of the genome also affects proteinexpression and function, in a way that is not yet fully understood. Further advances in molecular biology and bioinformatics will make it possible to comprehensively understand the complex influence of SNPs on gene expression, protein expression and finally protein function. This will add its part to the understanding of the complex network of determinants underlying individual response to anticancer therapy.

Furthermore, FISH analysis is routinely performed to assess general cytogenetics and in particular disease-related chromosomal disorders, e.g. chronic myelogenous leukemia, acute lymphoblastic leukemia and Down syndrome. For prediction of response to anticancer therapy, the FISH technique has been primarily used to determine the copy number of the HER-2 gene to select for HER-2 targeted therapies such as trastuzumab and lapatinib in breast cancer. Therefore, the determination of HER-2 gene amplification by FISH technique is widely used in clinical trials evaluating HER-2 targeted therapies [180-183]. In the analysis of response to targeted anticancer therapy, FISH is mainly used to investigate relationships between the copy number of a gene, encoding a target protein and individual response to therapy $[184,185]$.

\section{DNA microarray profiling}

A DNA microarray is a multiplex technology used to simultaneously measure expression levels of thousands of genes. RT-PCR applications are generally the techniques of choice, based on the enhanced sensitivity with the ability to detect RNA over a seven-log range. This technology has been miniaturized on small silicon chips or glass slides with the feasibility to accommodate over 30,000 oligonucleotides or cDNAs and has thus adapted to highthroughput performance. The huge amount of data produced by those experiments is being analyzed by pattern recognition software, using clustering algorithms for the identification of groups of genes whose expression varies in the same way between groups. Bioinformatic data mining has the potential to reveal unknown patterns of relationships between genes, in context to response mechanisms to anticancer therapy.

The identification of gene sets with a functional role in chemosensitivity may provide assistance in the choice of patient-tailored therapeutic regimens and for therapeutic intervention in drug-resistant disease.

Since more than 100,000 compounds were screened for anticancer activity patterns against the NCI60 cell line panel and the resulting data has revealed information on the mechanisms of action and resistance of those compounds [205-207], several genomic studies have been conducted using the well characterized NCI60 cell line panel as a basis. The p53 tumor suppressor pathway [208], membrane transporters and channels [209], reductase enzyme expression [210], EGFR expression and amplification [211], P450 enzyme expression [212] and MRP expression [213] are some examples for the investigations of relationships between distinct gene expression patterns and response to anticancer therapy based on the NCI60 panel. Among others, Weinstein and colleagues have analyzed gene expression patterns of the NCI60 panel on the basis of activity patterns of compounds [207, 214]. To improve the reliability of gene signatures predictive for chemosensitivity, robust methods for combining microarray expression data with NCI60 chemosensitivity data were developed. Algorithms for predicting chemosensitivity were optimized based on different bioinformatic filter- and cluster approaches $[215,216]$. The bioinformatic approach called the co-expression extrapolation (COXEN) algorithm has 
been shown to be useful in the NCI60 panel to predict chemosensitivity, even in cell lines of histological types not included in panel. That led to the question, whether this approach could be used to predict drug sensitivity in different patient's primary tumors. A modification of the COXEN algorithm has been demonstrated to be potentially applicable to bypass the intermediate animal model and achieve predictability of response to anticancer therapy in the clinic situation [217].

Results from the NCI60 panel were also observed in other cell line panels, e.g. the classification of drugs based on their modes of action [218]. Based on these results, Nakatsu et al. complemented the JFCR-39 cell line panel and developed an integrated database of chemosensitivity correlated with gene expression for this new cell line panel, called JFCR-45. This revealed candidate genes which may be related to chemosensitivity. To proof this, the ability of these candidate genes to alter chemosensitivity after being individually over-expressed was examined [219]. Another panel consisting of 30 cell lines was also used in a study, which focused on chemoresistance to in vivo concentrations achieved by anticancer drugs. Gene expression patterns provided 76 new candidate genes with associations to multidrug-resistance. This may allow prediction of response to anticancer therapy in a clinical situation [220]. Sekine et al. published in 2007 [221], highlighting genes which potentially regulate chemosensitivity of tumor cell lines to anticancer therapy. Furthermore, comprehensive studies correlating gene expression patterns and chemosensitivity were conducted using human tumor xenografts $[88,89,222]$. A genomewide study, analyzed gene expression profiles of 85 cancer xenografts in mice that had been established from nine different human organs. The applied cDNA microarray consisted of 23,040 genes, used to study those xenografts. The study resulted in the identification of 1,578 genes whose expression levels correlated significantly with chemosensitivity [223]. All these studies suggest that the combination of unbiased genome-wide chemosensitivity analysis using array-based approaches may identify candidate genes or gene sets with the capacity to predict cancer cell chemosensitivity. It is important, that these candidate genes or gene sets identified in these functional approaches still require extensive validation in vivo before they can be considered as putative biomarkers and find application in the clinical setting. Therefore, several studies were conducted in patient cohorts to identify predictive biomarker for anticancer therapy directly in the clinical setting. Clinical trials were carried out for different tumor entities, e.g. colorectal cancer [224, 225], oesophageal cancer [226], epithelial ovarian cancer [227], pancreatic cancer [228] and breast cancer [229, 230].
These studies reported on gene signatures that may enable prediction of the response to anticancer therapy. Even though these studies were carried out directly in patient cohorts, the resulting predictive signatures have to be validated in independent studies, with a more significant number of patients. The instability of gene expression signatures derived merely from associative studies has been documented [231-233] and contributes to failed attempts to identify gene expression patterns predictive of response to anticancer therapy. Consequently, DNA microarray analyses of small clinical trial cohorts may not yield gene signatures with power sufficient to predict chemosensitivity [234]. Furthermore, tissue sampling and quality have a major impact on profiling results, due to the fact that transcriptional profiles are the sum of mRNA expression contributed by all tissue components [170]. Individual tumor mRNA expression heterogeneity and the varying tumor content in clinical samples, may give a significantly impaired transcriptional profile among samples [235]. The interpretation of microarray results is also difficult in that complex bioanalytic and bioinformatical analysis techniques are used, which are not yet fully standardized. Nonetheless, the analysis of gene expression patterns greatly contributes to the understanding of the complex cellular mechanisms underlying individual response to anticancer therapy.

Currently, commercialized microarray-based multigene assays are already available. For example, the MammaPrint assay (Agendia BV, Amsterdam, The Netherlands) comprising 70 genes, which is currently designed as a pure prognostic assay for women under the age of 61 with either ER-positive or ER-negative, lymph node negative breast cancer [236]. This assay has not yet been shown to be able to predict sensitivity to anticancer treatment. The oncotype $\mathrm{DX}^{\mathrm{TM}}$ is a 21 -gene, prognostic and predictive assay that determines the 10-year risk for disease recurrence in patients with ER-positive, lymph node negative tumors. In contrast, this assay has been reported to predict benefit from tamoxifen treatment in patients with a low or intermediate risk score and benefit from chemotherapy in those with a high-risk score [237]. A combination of several pharmacogenomic gene sets, designed primarily as a predictive test for guiding selection of therapy is called the NuvoSelect ${ }^{\mathrm{TM}}$ assay. One of the used gene sets consisting of 30 genes predicts response to preoperative combination treatment with paclitaxel, 5-fluorouracil, doxorubicin, and cyclophosphamide (TFAC). Another gene set predicts clinical outcome after 5 years of endocrine therapy [238].

In summary, the collection of huge databases of gene expression studies will hopefully reveal a comprehensive picture of the genomics of cancer and contribute its part to individualized anticancer therapy. 


\section{Proteomics}

Functionally, cancer is a genomic as well as a proteomic disease. While the basic information for the production of proteins is encoded by the genome, only subsets of the possible protein products abundant in the cell are displayed in the genetic code. Finally, the structure of protein products and their functional status often depend on posttranslational modifications, such as phosphorylation, glycosylation and proteolytic cleavage that are not reflected in their genomic sequences. Furthermore, gene expression often does not correlate with the protein expression or the functionality of the encoded protein [239, 240]. Since, cellular signal transduction is mostly a post-translationally driven process, it seems obvious to directly investigate the protein-driven signaling cascades by the use of proteomics [241]. Proteomics is a recent member of the 'omics' family and describes the study of the wide complement of cellular proteins, their subcellular localization, turnover and interaction with other proteins. In contrast to the genome, the proteome is at a constant flux due to diverse environmental influences. Therefore, the proteome is significantly more challenging to map, compared to the genome [242]. Alterations within the proteome also have a potentially higher functional impact than modifications in the genome, because they are more likely to contribute to a drugresistant phenotype [243].The analysis of proteins and protein networks in cancer using proteomic technologies is known as oncoproteomics (Fig. 5). Given that the proteome of a cell is responsible for key-biologic processes and therefore also makes up the bulk of pharmaceutical targets, oncoproteomics has the potential to revolutionize clinical practice. This includes cancer diagnosis, development and individualized selection of therapies that target exclusively the cancer-specific protein networks, and real-time assessment of therapeutic efficiency and toxicity. Proteins are traditionally measured using low-throughput techniques such as western blotting, in situ hybridization and immunohistochemical staining [244]. Two-dimensional (2D) gel electrophoresis is a widely used technique in proteomic research, due to its high resolving power that permits simultaneous visualization of primary and post-translationally modified gene products in a single gel [245, 246]. This technology has been used to separate proteins on the basis of their size and charge. In combination with mass spectrometry for protein identification this is a widely used approach for the discovery of several biomarker candidates. Matrix-assisted laser desorption and ionization with time-of-flight detection mass spectrometry (MALDI-TOF), surface-enhanced laser desorption and ionization with time-of-flight spectrometry (SELDI-TOF) and antibodybased protein microarrays are modern methods for a rapid and more sensitive high-throughput detection and identification of both known and unknown proteins [247]. In contrast to mass spectrometry-based biomarker discovery, antibody-based profiling requires prior knowledge of the proteins that are going to be investigated. Therefore, the identification of previously unknown protein biomarker candidates is restricted to MS-based discovery approaches. Antibody-based approaches, such as protein microarrays became more and more important with the introduction of targeted anticancer therapy. These technologies are potentially able to map the activation status of cellular signaling pathways comprehensively, which will have a strong impact on individualized treatment concepts and monitoring of response to therapy. Nearly all proteomic techniques that are usually used for molecular analysis in several biomedical fields are also applied in the study of response to therapy in human cancers [248-250]. Oncoproteomics will play an important role in gaining new insights into cancer development and progression as well as in the discovery and validation of new protein targets for diagnostics and prediction of response to anticancer therapy [251-253]. Furthermore it will be a great challenge to acclimatize proteomic technologies for regular use in clinical laboratories.

\section{D electrophoresis}

Two-dimensional gel electrophoresis (2DE) is one of the oldest approaches and one of the most powerful protein separation methods available today. The first-dimensional separation of samples is achieved by isoelectric focusing (IEF), which separates proteins on the basis of their charge. Two types of IEF techniques are currently used: the immobilized $\mathrm{pH}$ gradient (IPG) technique; and the nonequilibrium $\mathrm{pH}$ gradient gel electrophoresis (NEPHGE). The second-dimensional separation is performed using sodium dodecyl sulfate-polyacrylamide gel electrophoresis [254]. The 2DE provides the capability to qualitatively and quantitatively resolve complex protein mixtures to unique spots $[255,256]$. The measured protein patterns can be analyzed using sophisticated, bioinformatical software to reveal those proteins that are differentially expressed between samples.

2D-DIGE is an important proteomic tool, especially for translational research involved in biomarker discovery. When absolute biological variation between samples is the main objective, as it is in biomarker discovery, 2D-DIGE is still one of the methods of choice [257]. Several studies were published, identifying novel prognostic or predictive biomarkers, e.g. biomarkers of drug-resistance [258-261]. First experiments, to study resistance to anticancer therapy using 2DE techniques were performed back in 1986, when 
Fig. 5 Exemplary illustration of different proteomic approaches used in translational research

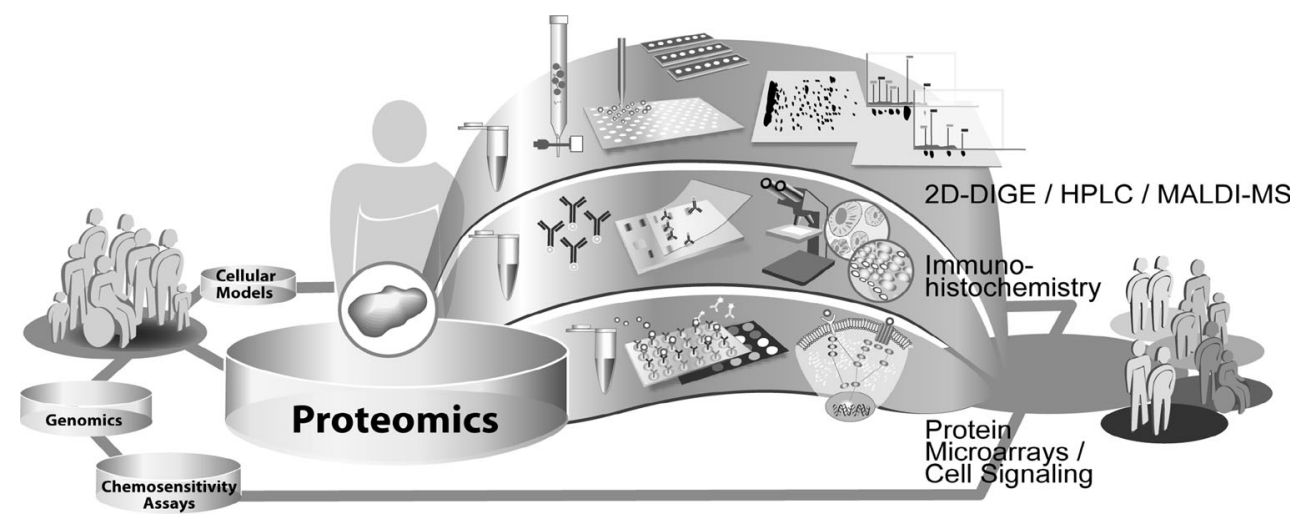

Shen et al. [262] investigated the mechanisms of multidrug resistance in human cancer cells. Since then, experimental techniques have continuously been improved and modified for various study designs $[263,264]$. For example, Tanaka et al. adapted the 2DE technique for a comparative proteomic analysis of basic proteins. In this study, cancer cell lines were analyzed with regard to their chemosensitivity, using a radical-free and highly reducing method of twodimensional polyacrylamide gel electrophoresis [265]. This technique is reported to have a superior ability in the separation of basic proteins and the quantification of posttranslational modifications, compared to traditional $2 \mathrm{DE}$ [266]. Different prefractionation methods, prior to $2 \mathrm{DE}$ analysis, as well as various combinations of analysis technique have also been developed to gain detailed knowledge of cellular mechanisms involved in response to anticancer therapy. Based upon these developments, detailed studies of different cellular components and protein signaling networks have also been conducted, e.g. the subcellular proteome [267, 268], the phosphoproteome [269], mitochondrial proteome [270] .Using comparative proteomic approaches, long lists of differentially expressed proteins, potentially involved in chemoresistance mechanisms were published, and reviewed by Zhang et al. [271]. Besides studies based on secondary cell lines, these techniques also found application in the clinical setting [272, 273]. In many studies, biomarker candidates were validated by alternative, more specific techniques such as RT-PCR and Northern blot at the mRNA level or Western blot and immunohistochemistry at the protein level. The identified proteins belonged to a variety of different classes of proteins. However, the limitations of this method include limited reproducibility and inability to detect low abundant proteins [274]. These low levels may result in undetectable proteins which significantly limit the application of this method to clinical samples. The combination of $2 \mathrm{DE}$ based with liquid chromatographic (LC) protein separation techniques [e.g. 296] and complete gel-free LC-MS approaches are more and more recognized.
Chromatographic techniques

An alternative, non-gel-based, protein separation approach to 2DE is Liquid Chromatography (LC) [275]. Basically, the components are separated using two phases, a stationary phase and a mobile phase. The procedure is mainly described by the elution of the different components at different rates, due to a varying affinity to interact with the used matrix, which results in a physicochemical separation. This technology is basically used for protein or peptide separations, prior to MS analysis and has been improved to handle proteomic analyses of complex samples [276]. Various chromatography techniques have been developed as methods for protein separation, e.g. reversed-phase [277], cation exchange [278], anion exchange [279], biphasic ion-exchange [280] or size-exclusion [281]. Single- and multidimensional LC can directly be interfaced with the mass spectrometry (MS), enabling automated analysis of large amounts of data for subsequent protein identification [282]. Another 2D chromatographic strategy termed multidimensional protein identification technology (MudPIT) has been extensively applied to proteomic analysis. Mud-PIT is in principle a technique in which two liquid chromatographic steps are interfaced back-to-back in a fused silica capillary to permit two-dimensional highperformance liquid chromatography, combined with mass spectrometry for protein identification [283, 284]. However, the application of tryptic digestion of proteins in these technologies introduces some limitations. Unfortunately, the tryptic digestion of protein samples results in a loss of basic information about the intact proteins, e.g. posttranslational modifications. Furthermore, low abundance proteins from a complex mixture may not be detectable in the presence of various peptides originating from other proteins. Therefore, the separation of intact proteins by liquid chromatography may offer advantages over tryptic approaches and the use of gel-based methods. In general, these technologies show advantages over gel-based techniques with regard to speed, sensitivity, scope of analysis 
and dynamic range [285]. In the field of oncoproteomics these methods have been integrated in the mass spectrometry-based discovery and characterization of novel biomarker candidates for guiding individualized anticancer therapy (e.g.) [286, 287].

\section{Mass spectrometry (MALDI TOF MS, SELDI TOF MS)}

Mass spectrometry is a method of choice for analytical characterization of potential drug molecules and protein identification. This technology is widely used to detect and identify the chemical composition of samples, after ionization, on the basis of their mass-to-charge ratio $(\mathrm{m} / \mathrm{z})$. As described earlier, mass spectrometry is often combined with different protein separation techniques to discovery of protein biomarker. Many variants of mass spectrometrybased approaches have been developed for gel-free proteomic analysis. These methodologies apply different prefractionation techniques, such as selective surface binding (SELDI), magnetic bead pre-fractionation or liquid chromatography (LC-MALDI). The basic principle of the surface-enhanced laser desorption/ionization- time of flight (SELDI-TOF) and the matrix-assisted laser desorption/ ionization (MALDI) techniques is the fact that the sample is pulsed with laser energy causing proteins or protein fragments to ionize, and fly through a vacuum tube to the detector plate. Their time of flight is affected by the mass of the particle and its charge $(\mathrm{m} / \mathrm{z}$ ratio). The detector plate records the intensity of the signal at a given $\mathrm{m} / \mathrm{z}$ value, and a spectrum is generated. The different peaks in the spectrum correspond to different $\mathrm{m} / \mathrm{z}$ protein species. SELDITOF is a proteomic technology used for the quantitative analysis of protein mixtures after selectively capturing proteins on pretreated surfaces. In contrast to the MALDI technology, the SELDI technology uses selective surfaces for binding a subset of proteins based on absorption, partition, electrostatic interaction or affinity chromatography on a solid-phase protein chip surface. Therefore, stainless steel or aluminum-based chips are coated with chemicals (e.g., anionic, cationic, hydrophobic, hydrophilic, or immobilized metal affinity) or biological substances (e.g., antibodies, antigen binding fragments such as $\mathrm{scFv}$, or receptor) to capture protein samples based on their intrinsic properties. These pre-fractionation steps enable the detection of low abundant proteins. Until now, SELDI has mainly been used to characterize patients at risk of the development of cancer based on the direct analysis of body fluids like serum, plasma, and urine [288-290]. Nonetheless, there are approaches to use SELDI-TOF as a clinical proteomics tool for the identification of protein biomarker candidates, being predictive for response to anticancer therapy [90, 291-293].
In general, MALDI techniques immobilize protein samples in an energy absorbing matrix. The entire repertoire of proteins in the sample interacts with the matrix from which a selected subset of proteins is bound to, a function of the composition of the selected matrix. The matrix chemicals absorb energy, which is subsequently passed to the sample proteins. Protein structural information, such as peptide molecular weight, amino-acid sequence composition, type and location of post-translational modification, could be obtained by MS analysis. Two MS technologies are common and widely used, the matrix-assisted laser desorption ionization time of- flight mass spectrometry (MALDI-TOF-MS) and the electrospray ionization mass spectrometry (ESI-MS). MALDITOF-MS generates ions from solid-phase samples and measures their mass in a flight tube, whereas ESI-MS generates ions from liquid samples and measures their mass using either quadrupole or time of flight detector. MALDI-MS is the most commonly used technique for peptide mass fingerprinting [294, 295]. MALDI-MS is a fast, robust, easy to perform, sensitive (low fmol range), and accurate (low ppm range) technology, which can be adapted to high-throughput [296]. LC-MALDI approaches have also been used to identify protein biomarker for the prediction of response to anticancer therapy. These studies were performed using cell lines, as well as patient's tumor and serum samples [297-301]. Mass spectrometry technologies in combination with protein separation techniques have the ability to investigate complex patterns of protein expression and modification. Despite the complexity of the human proteom, the constantly improved proteomic technologies will ultimately enable the measurement of individual molecular profiles of patients on the protein level, with the potential to guide personalized medicine.

\section{Immunohistochemistry}

Similar to the western blot technology, immunohistochemistry is a well-known method which has developed over the years with respect to reproducibility and sensitivity. In 1941 already, Coons et al. [302] published a paper describing an immunofluorescence technique for detecting cellular antigens in tissue sections, which marked the beginning of immunohistochemistry (IHC). The fundamental concept behind IHC is the detection of antigens within tissue sections using specific antibodies. Once antigen-antibody binding occurs, a colored histochemical reaction becomes visible by light microscopy or in the case of fluorochromes using ultraviolet light. Immunohistochemistry (IHC) has long been used as an adjunctive diagnostic tool in a variety of cancers. It has provided clinicians with correlative insight into potential prognosis and differential diagnosis. The initially simple method of 
IHC has become more complex over the years. Currently, extremely sensitive methods are available to detect one or multiple antigens simultaneously or even to examine hundreds of tissues in the same section for the presence of a particular Antigen (microarray technology).

Automation using automated slide stainer increased throughput and reproducibility. Automated staining according to very stringent and standardized conditions has become more and more important since the introduction of targeted anticancer therapy, wherein target expression is one of the essential preconditions. For example, HER2 testing has become an important part of the clinical evaluation of all breast cancer patients throughout different countries, and accurate HER2 results are necessary for identifying patients who benefit from HER2-targeted therapy. IHC analysis is deeply integrated in breast cancer treatment by being able to determine the HER-2 status, the testing of progesterone receptor, estrogen receptor and the proliferation marker Ki-67 [303, 304]. Hence IHC is routinely used to predict response to both HER-2 and hormonal targeted therapies, but is not yet suitable for the prediction of either efficiency or toxicity of anticancer drugs.

Furthermore, IHC is often being used to validate findings from alternative proteomic studies. For example the validation of prognostic and predictive protein biomarker candidates derived from cell line experiments is commonly performed in clinical tumor samples [305-307]. The validation of proteomic-based discovery using clinical specimen is reviewed by Hewitt et al. [308]. Although, antibody signals can be directly assigned to cellular localizations and thus laser microdissection is not required, IHC results are nonetheless influenced by pre-analytic tissue processing and antigen retrieval. Inconsistent quality of IHC reagents and antibodies is also discussed to influence robustness of IHC results [309]. Despite automation and knowledge, IHC, still lacks uniformity of technique, appropriate controls, and standardization of antibodies and grading techniques, making it difficult to compare results across institutions, laboratories and experiments. The statistical analysis of IHC-based multiple markers may be complicated by the nonlinear nature of IHC staining, the impact of different slide scoring thresholds for different immunostains and different subcellular localization of markers. Limitations of IHC have been addressed by other techniques, including isotopic labeling and in situ hybridization, which allow for more quantitative analysis of variations in protein expression.

\section{Protein microarrays}

Protein microarrays, one emerging class of proteomic technologies, have broad applications for discovery and quantitative analysis of protein expression patterns [310, 311]. This technology is uniquely suited to generate an overview map of known cellular signaling proteins and their activation status, reflecting the state of information flow through cellular networks in individual specimens. In the simplest sense, protein microarrays are immobilized protein spots [312, 313]. Thus, proteins can be arrayed on solid surfaces, capillary systems or immobilized on beads [314, 315]. The spots may be homogeneous or heterogeneous and may consist of a bait molecule, such as an antibody, a cell or phage lysate, a nucleic acid, drug or a recombinant protein or peptide [316]. In the array, detection is achieved by probing with a tagged antibody, ligand or serum/cell lysate. The most advanced format of this technique is the antibody-microarray, in which the targeted proteins are detected by specific antibodies, which were coated on solid surfaces [317]. The reverse-phase protein microarrays (RPPA) for example, immobilize one sample per array spot, enabling an array to comprise hundreds of different cellular lysates or patient samples. The detection of proteins is conducted using phosphospecific and total protein antibodies to determine the activation status of key signaling molecules. This technology has been widely been used to analyze distinct cellular signaling pathways or to screen cell line panels as well as collections of clinical specimens for disease-related protein expression patterns. For example, Jones et al. [318] comprehensively analyzed the protein interaction network for the ErbB receptor family, which may have implications in epidermal growth factor receptor targeted anticancer therapy. Chan et al. [319], first showed the application of multiplexed reverse-phase protein microarrays to the study of signaling kinetics and pathway delineation in a leukemic $\mathrm{T}$ lymphocytes cell line after activation of certain receptors. An example of for the use of RPPA to screen protein expression patterns in cell line panels is a study of Nishizuka et al. [320], screening the NCI60 cell line panel using a reverse-phase protein lysate microarray. A finding from this study was that the patterns of protein expression compared with those obtained for the same genes at the mRNA level showed a striking regularity. Cell-structurerelated proteins almost invariably showed a high correlation between mRNA and protein levels across the NCI60 cell lines, whereas non-cell-structure-related proteins showed poor correlations. They also proposed that, this technology can be expected to contribute significantly to the identification of molecular markers and targets for individualized anticancer therapy. On this basis, Ma et al. [321] determined whether proteomic signatures of untreated cancer cells were sufficient for the prediction of drug response using the NCI60 panel. In this study, a machine learning model system was developed to classify cell line chemosensitivity exclusively based on RPPA 
proteomic profiling. The accuracy of chemosensitivity prediction of all the evaluated 118 anticancer agents was significantly higher $(P<0.02)$ than that of random prediction. This study provided a basis for the prediction of drug response based on protein markers in the untreated tumor. Cell line panels find broad application in the proteomic analysis of individual chemosensitivity and drug discovery [322-325]. Protein microarray platforms that can provide a quantitative, multiplexed read-out for cellular signaling and that can utilize microscopic quantities of tissue specimens for upfront analysis are needed for the implementation of this technology in the clinical situation [326] Therefore, the RPPA format has been improved to be able to measure the abundance of many specific proteins in complex solutions and has been adapted to use of very small amounts of protein, [327]. Thus, this technology is well suited for signal transduction profiling of clinical samples, e.g. biopsy specimens [316, 328, 329]. The identification of critical nodes or interactions within these networks is essential to drug development and the design of individualized anticancer therapy [330], especially with targeted drugs $[331,332]$. Using breast cancer as an example, Wulfkuhle et al. [241] stated that, phosphoprotein-driven cellular signaling events represent most of the new molecular targets for anticancer therapy. Therefore, the application of reverse-phase protein microarray technology for the study of ongoing signaling activity within breast tumor specimens holds great potential for elucidating and profiling signaling activity in realtime for patient-tailored therapy. Moreover, their data demonstrate the requirement of laser capture microdissection (LCM) for analysis and reveal the metastasisspecific changes that occur within a new microenvironment. Microdissection should be a necessary component of molecular analysis since dramatic changes within specific protein phosphorylation levels were noted between a majority of the undissected and microdissected samples. Laser capture microdissection technology permits a selection of a homogenous tumor population from a field of normal-appearing cells and vice versa, to improve the accuracy of comparative proteomics studies. Furthermore, Haab et al. [327] noted that, the sensitivity of individual antibody-antigen interactions for any given detection system are highly dependent on the relative abundance of the antigen-antibody species and the binding affinities between the probe antibodies and the immobilized antigens. Liotta et al. [333] reported on the analytical challenges faced by protein arrays and proposed a practical guide for optimizing construction and study design. Additionally, a difficulty is associated with preserving proteins in their biologically active conformation before analysis. This will further limit the application of this technology as a routine proteomic strategy, unless clinical samples are routinely taken by the use of highly specified procedures. The broad application of protein arrays in personalized medicine is also impaired by the costs of producing antibodies and the limited availability of antibodies with high specificity and high affinity for the target. Nevertheless, protein microarrays in combination with technologies such as LCM and high standardization will greatly contribute to the improved description of the multifactorial network, underlying individual response to anticancer therapy and will allow the design of personalized medicine.

\section{Discussion}

For most of the history of medicine, doctors relied on their senses-mainly vision, hearing, and touch-to diagnose illness and monitor a patient's condition. Since then, biomedical research has made huge progress in diagnosis and treatment strategies. The traditional trial-and-error practice of medicine is progressively eroding in favor of more precise marker-assisted diagnosis and safer and more effective molecularly guided treatment of disease. The aim of personalized medicine is to tailor disease detection, diagnosis and therapy to each individuaĺs profile, using molecular profiles to predict disease development, progression, clinical outcome and response to anticancer therapy. Recent advances in high-throughput technologies have raised new opportunities in the fields of personalized- and predictive medicine. Thus, enabling researchers to screen the whole genome, proteome, transcriptome, and metabolome for biomarkers, in tumor tissues and body fluids [334]. In addition, new cellular models such as 3D organoid cultures or spheroid systems opened new opportunities in drug discovery and translational research. These models reflect the in vivo situation much better than common $2 \mathrm{D}$ models which are however, well suitable for high-throughput screenings. The introduction of modern technologies such as mass spectrometry and protein and DNA arrays, combined with the understanding of the human genome, has enabled simultaneous examination of thousands of proteins and genes in single experiments. These technologies are capable of performing parallel analysis, in contrast to serial analysis conducted with older methods. Due to the variety of data points, they provide opportunities to identify distinguishing patterns for cancer diagnosis and classification as well as for prediction of response to anticancer therapies. Furthermore, these technologies provide the means by which new tumor markers could be discovered. At the current stage, the molecular prediction of response to anticancer therapy is more exploratory, aiming at advancing scientific knowledge within clinical investigations rather than routine in clinical practice. 
Although numerous biomarkers have been discovered, only a handful of them, such as HER2 amplification, BCR-ABL translocation, KRAS, BRAF and EGFR mutations have been validated for the use in the clinical reality [335].

Molecular research in human tumors is currently predominantly performed retrospectively, using residual tissue specimens obtained from surgical resection procedures. Those tissues are used for generating hypotheses regarding the clinical relevance of the observed markers in the studied patient populations, target validation, and assay optimization. Often these tissue samples are obtained by core needle biopsies, e.g. fine needle aspiration, resulting in small sample amounts, which are often insufficient for comprehensive molecular analysis with currently available technologies. Therefore, the miniaturization of new emerging technologies is urgently needed.

Furthermore, several studies have shown that tissue samples change their molecular profiles and start degrading immediately after resection from the patient's blood supply. Several exogenous factors such as ischemia time, drugs administered during surgery and processing protocols have been identified, which affect the molecular and genetic profiles of human tissue samples before, during and after the surgical resection [336]. We propose that tissue samples that reflect molecular reality are a requirement to enable efficient cancer drug profiling and biomarker discovery [337]. Besides technology-based challenges, regulatory issues are also limiting factors in the development of personalized medicine and predictive biomarkers. The clinical validation of putative functional regulators of drug response will run the risk of failure similar to other biomarker development efforts unless strict reporting guidelines are adhered to. Finally, the NCI-EORTC recommends that predictive biomarker studies require even stricter considerations, requiring validation in large randomized trials with sufficient power to detect drug-specific differences in tumor response [192]. Using, combining and further improving state of the art technologies and establishing stringent guidelines, the individualization of anticancer therapy especially in second-line treatment, will become accomplishable.

\section{Acknowledgments We thank BlackPool Design for the preparation of original figures.}

Conflict of interest The authors declare that there is no conflict of interest.

Open Access This article is distributed under the terms of the Creative Commons Attribution License which permits any use, distribution, and reproduction in any medium, provided the original author(s) and the source are credited.

\section{References}

1. Silberstein GB (2001) Tumor-stromal interactions role of the stroma in mammary development. Breast Cancer Res 3:218-223

2. Schmeichel KL, Bissell MJ (2003) Modeling tissue-specific signaling and organ function in three dimensions. J Cell Sci 116:2377-2388

3. ATCC The Global Bioresource Center http://www.lgcstandardsatcc.org/ATCCCulturesandProducts/tabid/979/Defaultaspx. Accessed 23 July 2011

4. DSMZ German Collection of Microorganisms and Cell Cultures http://www.dsmz.de/human_and_animal_cell_lines/main.php? menu_id=2. Accessed 23 July 2011

5. Smith V, Dai F, Spitz M, Peters GJ, Fiebig HH, Hussain A, Burger AM (2009) Telomerase activity and telomere length in human tumor cells with acquired resistance to anticancer agents. J Chemother 21(5):542-549

6. Shoemaker RH (2006) The NCI60 human tumor cell line anticancer drug screen. Nature Rev Cancer 6:813-823

7. Dan S, Tunoda T, Kitahara O, Yanagawa R, Zembutsu H, Katagiri T, Yamazaki K, Nakamura Y, Yamori T (2002) An integrated database of chemosensitivity to 55 anticancer drugs and gene expression profiles of 39 human cancer cell lines. Cancer Res 62:1139-1147

8. Naasani I, Seimiya H, Yamori T, Tsuruo T (1999) FJ5002: a potent telomerase inhibitor identified by exploiting the diseaseoriented screening program with COMPARE analysis. Cancer Res 59:4004-4011

9. Nakatsu N, Yoshida Y, Yamazaki K, Nakamura T, Dan S, Fukui Y, Yamori T (2005) Chemosensitivity profile of cancer cell lines and identification of genes determining chemosensitivity by an integrated bioinformatical approach using cDNA arrays. Mol Cancer Ther 4(3):399-412

10. Yaguchi S, Fukui Y, Koshimizu I, Yoshimi H, Matsuno T, Gouda H, Hirono S, Yamazaki K, Yamori T (2006) Antitumor activity of ZSTK474 a new phosphatidylinositol 3-kinase inhibitor. J Natl Cancer Inst 98:545-556

11. Yamori T, Matsunaga A, Sato S, Yamazaki K, Komi A, Ishizu K, Mita I, Edatsugi H, Matsuba Y, Takezawa K, Nakanishi O, Kohno H, Nakajima Y, Komatsu H, Andoh T, Suruo T (1999) Potent antitumor activity of MS-247 a novel DNA minor groove binder evaluated by an in vitro and in vivo human cancer cell line panel. Cancer Res 59:4042-4049

12. McDermott U, Sharma SV, Dowell L, Greninger P, Montagut C, Lamb J, Archibald H, Raudales R, Tam A, Lee DS, Rothenberg M, Supko JG, Sordella R, Ulkus LE, Maheswaran S, Njauw CN, Tsao H, Drew L, Hanke JH, Ma X, Erlander MG, Gray NS, Haber DA, Settleman J (2007) Identification of genotype-correlated sensitivity to selective kinase inhibitors by using highthroughput tumor cell line profiling. PNAS 104:19936-19941

13. Sharma SV, Haber DA, Settleman J (2010) Cell line-based platforms to evaluate the therapeutic efficacy of candidate anticancer agents. Nature reviews cancer 10:241-253

14. Mc Dermott U, Sharma SV, Settleman J (2008) High-throughput lung cancer cell line screening for genotype-correlated sensitivity to an EGFR kinase inhibitor. Meth Enzymol 438:331-341

15. Liu X, Ory V, Chapman S, Yuan H, Albanese C, Kallakury B, Timofeeva OA, Nealon C, Dakic A, Simic V, Haddad BR, Rhim JS, Dritschilo A, Riegel A, McBride A, Schlegel R (2012) ROCK inhibitor and feeder cells induce the conditional reprogramming of epithelial cells. Am J Pathol 180:599-607. doi:10. 1016/j.ajpath.2011.10.036

16. Semjen BV, Becker KF, Sinski A, Blennow S, Vietor I, Zatloukal K, Beug H, Wagner E, Huber LA (2002) Novel colon 
cancer cell lines leading to better understanding of the diversity of respective primary cancers. Oncogene 21:4646-4662

17. Allinen M, Beroukhim R, CaiL, Brennan C, Lahti-Domenici J, Huang H, Porter D, Hu M, Chin L, Richardson A, Schnitt S, Sellers WR, Polyak K (2004) Molecular characterization of the tumor microenvironment in breast cancer. Cancer Cell 6:17-32

18. Chung LWK, Baseman A, Assikis V, Zhau HE (2005) Molecular insights into prostate cancer progression: the missing link of tumor microenviroment. J Urol 173(1):10-20

19. Campling BG, Pym J, Baker HM, Cole SPC, Lam YM (1991) Chemosensitivity testing of small cell lung cancer using the MTT assay. Br J Cancer 63:75-83

20. Mechetner E, Brünner N, Parker RJ (2011) In vitro drug responses in primary and metastatic colorectal cancers. Scand $\mathbf{J}$ Gastroenterol 46:70-78

21. Yamaue $H$, Tanimura $H$, Nakamori M, Noguchi K, Iwahashi M, Tani M, Hotta T, Murakami K, Ishimoto K (1996) Clinical evaluation of chemosensitivity testing for patients with colorectal cancer using MTT assay. Dis Colon Rectum 39:416-422

22. Yamaue H, Tanimura H, Noguchi K, Hotta T, Tani M, Tsunoda T, Iwahashi M, Tamai M, Iwakura S (1992) Chemosensitivity testing of fresh human gastric cancer with highly purified tumor cells using the MTT assay. Br J Cancer 66:794-799

23. Kaspers GJL, Pieters R, Van Zantwijk CH, De Laat PAJM, De Waal FC, Van Wering ER, Veerman AJP (1991) In vitro drug sensitivity of normal peripheral blood lymphocytes and childhood leukaemic cells from bone marrow and peripheral blood. Br J Cancer 64:469-474

24. Larsson R, Kristensen J, Sandberg C, Nygren P (1992) Laboratory determination of chemotherapeutic drug resistence in tumor cells from patients with leukemia using a fluorometric microculture cytotoxicity assay (FMCA). Int $\mathrm{J}$ Cancer 50:177-185

25. Kurbacher CM, Cree IA (2003) Outcome of ATP-based tumor chemosensitivity assay directedchemotherapy in heavily pretreated recurrent ovarian carcinoma. BMC Cancer 3:19

26. Andreotti PE, Cree IA, Kurbacher CM, Hartmann DM, Linder D, Harel G, Gleiberman I, Caruso PA, Ricks SH, Untch M, Sartori C, Bruckner HW (1995) Chemosensitivity testing of human tumors using a microplate adenosine triphosphate luminescence assay: clinical correlation for cisplatin resistance of ovarian carcinoma. Cancer Res 55:5276-5282

27. Konecny G, Crohns C, Pegram M, Felber M, Lude S, Kurbacher C, Cree IA, Hepp H, Untch M (2000) Correlation of drug response with ATP Tumorchemosensitivity Assay in primary FIGO Stage III ovarian cancer. Gynecol Oncol 77:258-263

28. Dollner R, Granzow C, Neudert M, Dietz A (2006) Ex vivo chemosensitivity of head and neck carcinoma to cytostatic drug combinations. Anticancer Res 26:1651-1656

29. Dollner R, Granzow C, Helmke BM, Ruess A, Schad A, Dietz A (2004) The impact of stromal cell contamination on chemosensitivity testing of head and neck carcinoma. Anticancer Res 24:325-332

30. Neve RM, Chin K, Fridlyand J, Yeh J, Baehner FL, Fevr T, Clark L, Bayani N, Coppe JP, Tong F, Speed T, Spellman PT, DeVries S, Lapuk A, Wang NJ, Kuo WL, Stilwell JL, Pinkel D, Albertson DG, Waldman FM, McCormick F, Dickson RB, Johnson MD, Lippman M, Ethier S, Gazdar A, Gray JW (2006) A collection of breast cancer cell lines for the study of functionally distinct cancer subtypes. Cancer Cell 10(6):515-527

31. Sos ML, Michel K, Zander T, Weiss J, Frommolt P, Peifer M, Li D, Ullrich R, Koker M, Fischer F, Shimamura T, Rauh D, Mermel C, Fischer S, Stückrath I, Heynck S, Beroukhim R, Lin W, Winckler W, Shah K, LaFramboise T, Moriarty WF, Hanna M, Tolosi L, Rahnenführer J, Verhaak R, Chiang D, Getz G, Hellmich M, Wolf J, Girard L, Peyton M, Weir BA, Chen T,
Greulich H, Barretina J, Shapiro GI, Garraway LA, Gazdar AF, Minna JD, Meyerson M, Wong K, Thomas RK (2009) Predicting drug susceptibility of non-small cell lung cancers based on genetic lesions. J Clin Invest 119(6):1727-1740

32. Jacks T, Weinberg RA (2002) Taking the study of cancer cell survival to a new dimension. Cell 111:923-925

33. Griffith LG (2006) Swartz MA Capturing complex 3D tissue physiology in vitro. Nature Rev Mol Cell Biol 7:211-224

34. Teicher BA, Matoska J, Stricker F (1967) Following human tumours in primary organ culture. Neoplasma 14:507-519

35. Elliott NT, Yuan FA (2011) Review of three-dimensional in vitro tissue models for drug discovery and transport studies. J Pharm Sci 100:1

36. Martin Brown J (2002) Tumor microenvironment and the response to anticancer therapy. Cancer Biol Ther 1(5):453-458

37. Lewis C, Murdoch C (2005) Macrophage responses to hypoxia, implications for tumor progression and anti-cancer therapies. Am J Pathol 167(3):627-635

38. Sutherland RM, Durand RE (1976) Radiation response of multicell spheroids - an in vitro tumour model. Curr Top Radiat Res Q 11:87-139

39. Liu SC, Minton NP, Giaccia AJ, Brown JM (2002) Anticancer efficacy of systemically delivered anaerobic bacteria as gene therapy vectors targeting tumor hypoxia/necrosis. Gene Ther 9(4):291-296

40. Groebe K, Erz S, Mueller-Klieser W (1994) Glucose diffusion coefficients determined from concentration profiles in EMT6 tumor spheroids incubated in radioactively labeled L-glucose. Adv Exp Med Biol 361:619-625

41. Sutherland RM (1988) Cell and environment interactions in tumour microregions: the multicell spheroid model. Science 240(4849):177-184

42. David L (2008) Hyaluronan hydrogel: an appropriate threedimensional model for evaluation of anticancer drug sensitivity. Acta Biomater 4:256-263

43. Jungwoo L, Cuddihy MJ, Kotov NA (2008) Three-dimensional cell culture matrices: state of the art. Tissue Eng Part B 14(1):61

44. Kunz-Schughart LA, Kreutz M, Knuechel R (1998) Multicellular spheroids: a three-dimensional in vitro culture system to study tumour biology. Int J Exp Pathol 79:1-23

45. Wang F, Weaver VM, Petersen OW, Larabell CA, Dedhar S, Briand P, Lupu R, Bissell MJ (1998) Reciprocal interactions between $\beta 1$-integrin and epidermal growth factor receptor in three-dimensional basement membrane breast cultures: a different perspective in epithelial biology. Proc Natl Acad Sci USA 95:14821-14826

46. Tibbitt MW, Anseth KS (2009) Hydrogels as extracellular matrix mimics for 3D cell culture. Biotechnol Bioeng 103(4):655-663

47. Almany L, Seliktar D (2005) Biosynthetic hydrogel scaffolds made from fibrinogen and polyethylene glycol for 3D cell cultures. Biomaterial 15:2467-2477

48. Powers MJ, Domansky K, Kaazempur-Mofrad MR, Kalezi A, Capitano A, Upadhyaya A, Kurzawski P, Wack KE, Beer Stolz D, Kamm R, Griffith LG (2002) A microfabricated array bioreactor for perfused 3D liver culture. Biotechnol Bioeng 3:257-269

49. Nelson CN, Bissell MJ (2005) Modeling dynamic reciprocity: Engineering three-dimensional culture models of breast architecture function and neoplastic transformation. Semin Cancer Biol 15(5):342-352

50. O'Brien LE, Yu W, Tang K, Jou T, Zegers MMP, Mostov KE (2006) Morphological and biochemical analysis of Rac1 in three-dimensional epithelial cell cultures. Methods Enzymol 406:676-691

51. Serebriiskii I, Castello-Cros R, Lamb A, Golemis EA, Cukierman E (2008) Fibroblast-derived 3D matrix differentially 
regulates the growth and drug-responsiveness of human cancer cells. Matrix Biol 27:573-585

52. Olive P, Durand RE (1994) Drug and radiation resistance in spheroids: cell contact and kinetics. Cancer Metastasis Rev 13(2):121-138

53. Frankel A, Buckman R, Kerbel RS (1997) Abrogation of taxolinduced G2-M arrest and apoptosis in human ovarian cancer cells grown as multicellular tumor spheroids. Cancer Res 57:2388-2393

54. dit Faute MA (2002) Distinctive alterations of invasiveness drug resistance and cell-cell organization in 3D-cultures of MCF-7 a human breast cancer cell line and its multidrug-resistant variant. Clin Exp Metastasis 19:161-168

55. Hazlehurst LA, Landowski TH, Dalton WS (2003) Role of the tumor microenvironment in mediating de novo resistance to drugs and physiological mediators of cell death. Oncogene 22:7396-7402

56. Frankel A, Man S, Elliott P, Adams J, Kerbel RS (2000) Lack of multicellular drug resistance observed in human ovarian and prostate carcinoma treated with the proteasome inhibitor PS341. Clin Cancer Res 6:3719-3728

57. Eshleman JS, Carlson BL, Mladek AC, Kastner BD, Shide KL, Sarkaria JN (2002) Inhibition of the mammalian target of rapamycin sensitizes U87 xenografts to fractionated radiation therapy. Cancer Res 62:7291-7297

58. Liu M, Howes A, Lesperance J, Stallcup WB, Hauser CA, Kadoya K, Oshima RG, Abraham RT (2005) Antitumor activity of rapamycin in a transgenic mouse model of ErbB2-dependent human breast cancer. Cancer Res 65:5325-5336

59. Barbone D, Yang TM, Morgan JR, Gaudino G, Broaddus VC (2008) Mammalian target of rapamycin contributes to the acquired apoptotic resistance of human mesothelioma multicellular spheroids. J Biol Chem 283:13021-13030

60. Friedrich J, Ebner R, Kunz-Schughart LA (2007) Experimental anti-tumor therapy in 3-D: spheroids - old hat or new challenge? Int J Radiat Biol 83:849-871

61. Mueller-Klieser W (1987) Multicellular spheroids. A review on cellular aggregates in cancer research. J Cancer Res Clin Oncol 113:101-122

62. Friedrich J (2007) A reliable tool to determine cell viability in complex 3-d culture: the acid phosphatase assay. J Biomol Screen 12:925-937

63. Herrmann R, Fayad W, Schwarz S, Berndtsson M, Linder S (2008) Screening for compounds that induce apoptosis of cancer cells grown as multicellular spheroids. J Biomol Screen 13(1-8): 173

64. Kunz-Schughart LA, Freyer JP, Hofstaedter F, Ebner R (2004) The use of 3-D cultures for high-throughput screening: the multicellular spheroid model. J Biomol Screen 9:273

65. Friedrich J, Seidel C, Ebner R, Kunz-Schughart LA (2009) Spheroid-based drug screen: considerations and practical approach. Nat Protoc 4:309-324

66. Ertel A, Verghese A, Byers SW, Ochs M, Tozeren (2006) A pathway-specific differences between tumor cell lines and normal and tumor tissue cells. Mol Cancer 5:55

67. Ross DT, Perou CM (2001) A comparison of gene expression signatures from breast tumors and breast tissue derived cell lines. Dis Markers 17(2):99-109

68. Vescio RA, Redfern CH, Nelson TJ, Ugonetz S, Stern PH, Hoffman RM (1987) In vivo-like drug responses of human tumors growing in three-dimensional gel-supported primary culture. Proc NatI Acad Sci USA 84:5029-5033

69. Vescio RA, Connors KM, Kubota T, Hoffman RM (1991) Correlation of histology and drug response of human tumors grown in native-state three-dimensional histoculture and in nude mice. Proc Natl Acad Sci USA 88:5163-5166
70. Furukawa T, Kubota T, Watanabe M, Kase S, Takahana T, Yamaguchi H, Takeuchi T, Teramoto T, Ishibiki K, Kitajima M, Hoffman RM (1992) Chemosensitivity testing of clinical gastrointestinal cancers using histoculture and the MiT end-point. Anticancer Res 12:1377-1382

71. Ohie S, Udagawa Y, Aoki D, Nozawa S (2005) Histoculture drug response assay to monitor chemoresponse. Methods Mol Med 110:79-86

72. Ariyoshia Y, Shimaharaa M, Tanigawa N (2003) Study on chemosensitivity of oral squamous cell carcinomas by histoculture drug response assay. Oral Oncol 39:701-707

73. Singh S, Li R, Xu L, Poluri R, Patel S, Shaha AR, Pfister D, Sherman E, Goberdhan A, Hoffman RM, Shah J (2002) Prediction of survival in patients with head and neck cancer using the histoculture drug response assay. Head Neck 24(5): 437-442

74. Kubota T, Sasano N, Abe O, Nakao I, Kawamura E, Saito T, Endo M, Kimura K, Demura H, Sasano H, Nagura H, Ogawa N, Hoffman RM, Chemosensitivity Study Group for the Histoculture Drug-Response Assay (1995) Potential of the histoculture drug-response assay to contribute to cancer patient survival. Clin Cancer Res 1:1537-1543

75. Furukawa T, Kubota T, Hoffman RM (1995) Clinical applications of the histoculture drug response assay. Clin Cancer Res 1:305-311

76. Nakada S, Aoki D, Ohie S, Horiuchi M, Suzuki N, Kanasugi M, Susumu N, Udagawa Y, Nozawa S (2005) Chemosensitivity testing of ovarian cancer using the histoculture drug response assay: sensitivity to cisplatin and clinical response. Int J Gynecol Cancer 15:445-452

77. van der Kuip H, Mürdter TE, Sonnenberg M, McClellan M, Gutzeit S, Gerteis A, Simon W, Fritz P, Aulitzky WE (2006) Short term culture of breast cancer tissues to study the activity of the anticancer drug taxol in an intact tumor environment. BMC Cancer 6:86

78. Sachs N, Clevers H (2014) Organoid cultures for the analysis of cancer phenotypes. Curr Opin Genet Dev 24:68-73. doi:10. 1016/j.gde.2013.11.012 (Epub 2013 Dec 31)

79. Sato T, Stange DE, Ferrante M, Vries RG, van Es JH, Van den Brink S, Van Houdt WJ, Pronk A, Van GJ, Siersema PD, Clevers $H$ (2011) Long-term expansion of epithelial organoids from human colon, adenoma, adenocarcinoma, and Barrett's epithelium. Gastroenterology 141:1762-1772

80. Jung P, Sato T, Merlos-Suarez A, Barriga FM, Iglesias M, Rossell D, Auer H, Gallardo M, Blasco MA, Sancho E, Clevers $\mathrm{H}$, Batlle E (2011) Isolation and in vitro expansion of human colonic stem cells. Nat Med 17:1225-1227

81. Barretina J, Caponigro G, Stransky N, Venkatesan K, Margolin AA, Kim S, Wilson CJ, Lehar J, Kryukov GV, Sonkin D, Reddy A, Liu M, Murray L, Berger MF, Monahan JE, Morais P, Meltzer J, Korejwa A, Jane-Valbuena J, Mapa FA, Thibault J, Bric-Furlong E, Raman P, Shipway A, Engels IH, Cheng J, Yu GK, Yu J, Aspesi P Jr, de SM, Jagtap K, Jones MD, Wang L, Hatton C, Palescandolo E, Gupta S, Mahan S, Sougnez C, Onofrio RC, Liefeld T, MacConaill L, Winckler W, Reich M, Li N, Mesirov JP, Gabriel SB, Getz G, Ardlie K, Chan V, Myer VE, Weber BL, Porter J, Warmuth M, Finan P, Harris JL, Meyerson M, Golub TR, Morrissey MP, Sellers WR, Schlegel R, Garraway LA (2012) The cancer cell line encyclopedia enables predictive modelling of anticancer drug sensitivity. Nature 483:603-607

82. Vaira V, Fedeleb G, Pyneb S, Fasolia E, Zadrab G, Bailey D, Snyder E, Faversania A, Coggia G, Flavinc R, Bosaria S, Loda M (2010) Preclinical model of organotypic culture for pharmacodynamic profiling of human tumors. Proc Natl Acad Sci USA 107(18):8352-8356 
83. Trédan O, Galmarini CM, Patel K, Tannock IF (2007) Drug resistance and the solid tumor microenvironment. J Natl Cancer Inst 99:1441-1454

84. Voskoglou-Nomikos T, Pater JL, Seymour L (2003) Clinical predictive value of the in vitro cell line human xenograft and mouse allograft preclinical cancer models. Clin Cancer Res 9:4227-4239

85. Ekser B, Starzl TE (2010) Overcoming the barriers to xenotransplantation: prospects for the future. Expert Rev Clin Immunol 6(2):219-230

86. Smith V, Wirth GJ, Fiebig HH, Burger AM (2008) Tissue microarrays of human tumor xenografts: characterization of proteins involved in migration and angiogenesis for applications in the development of targeted anticancer agents. Cancer Genomics Proteomics 5:263-274

87. Fiebig HH, Maiera A, Burger AM (2004) Clonogenic assay with established human tumour xenografts: correlation of in vitro to in vivo activity as a basis for anticancer drug discovery. Eur $\mathbf{J}$ Cancer 40:802-820

88. Korrat A, Greiner T, Maurer M, Metz T, Fiebig HH (2007) Gene signature-based prediction of tumor response to cyclophosphamide. Cancer Genomics Proteomics 4:187-196

89. Fiebig HH, Schüler J, Bausch N, Hofmann M, Metz T, Korrat A (2007) Gene signatures developed from patient tumor explants grown in nude mice to predict tumor response to 11 cytotoxic drugs. Cancer Genomics Proteomics 4:197-210

90. Kelly P, Appleyard V, Murray K, Paulin F, Lamont D, Baker L, Suttie S, Exon D, Thompson A (2010) Detection of oesophageal cancer biomarkers by plasma proteomic profiling of human cell line xenografts in response to chemotherapy. $\mathrm{Br} \mathrm{J}$ Cancer 103:232-238

91. Mattern J, Bak M, Hahn EW, Volm M (1988) Human tumor xenografts as model for drug testing. Cancer Metastasis Rev $7(3): 263-284$

92. Sharpless NE, De Pinho RA (2006) The mighty mouse: genetically engineered mouse models in cancer drug development. Nat Rev Drug Discov 5:741-754

93. Kelland LR (2004) "Of mice and men": values and liabilities of the athymic nude mouse model in anticancer drug development. Eur J Cancer 40(6):827-836

94. Rubio-Viqueira B, Hidalgo M (2009) Direct in vivo xenograft tumor model for predicting chemotherapeutic drug response in cancer patients. Clin Pharmacol Ther 85:217-221

95. Black MM, Speer FD (1954) Further observations on the effects of cancer chemotherapeutic agents on the in vitro dehydrogenase assay activity of cancer tissue. J Natl Cancer Inst 14:1147-11581

96. Balkwill F (2009) Tumour necrosis factor and cancer. Nat Rev Cancer 9:361-371

97. Goldstein RH, Weinberg RA, Rosenblatt M (2010) Of mice and (wo)men: mouse models of breast cancer metastasis to bone. J Bone Miner Res 25(3):431-436

98. Firestone B (2010) The challenge of selecting the 'right' in vivo oncology pharmacology model. Curr Opin Pharmacol 10:391-396

99. Weislow OS, Kiser R, Fine DL (1989) New soluble-formazan assay for HIV-1 cytopathic effects: application to high-flux screening of synthetic and natural products for AIDS-antiviral activity. J Natl Cancer Inst 81:577-586

100. Skehan P, Storeng R, Scudiero D, Monks A, McMahon J, Vistica D, Warren JT, Bokesch H, Kenney S, Boyd MR (1990) New colorimetric cytotoxicity assay for anticancer-drug screening. J Natl Cancer Inst 82(13):1107-1112

101. Maehara Y, Anai H, Tamada R, Sugimachi K (1987) The ATP assay is more sensitive than the succinate dehydrogenase inhibition test for predicting cell viability. Eur J Cancer Clin Oncol 23(3):273-276
102. Keepers YP, Pizao PE, Peters GJ, Van Ark-Otte J, Winograd B, Pinedo HM (1991) Comparison of the sulforhodamine B protein and tetrazolium (MTT) assays for in vitro chemosensitivity testing. Eur J Cancer 27:897-900

103. Sekhon BK, Roubin RH, Tan D, Chan WK, Sze DM (2008) High-throughput screening platform for anticancer therapeutic drug cytotoxicity. Assay Drug Dev Technol 6(5):711-721

104. Rubinstein LV, Shoemaker RH, Paull KD, Simon RM, Tosini S, Skehan P, Scudiero DA, Monks A, Boyd MR (1990) Comparison of in vitro anticancer-drug-screening data generated with a tetrazolium assay versus a protein assay against a diverse panel of human tumor cell lines. J Natl Cancer Inst 82:1113-1118

105. Ugurel S, Schadendorf D, Pföhler C, Neuber K, Thoelke A, Ulrich J, Hauschild A, Spieth K, Kaatz M, Rittgen W, Delorme S, Tilgen W (2006) In vitro drug sensitivity predicts response and survival after individualized sensitivity-directed chemotherapy in metastatic melanoma: a multicenter phase II trial of the Dermatologic Cooperative Oncology Group. Clin Cancer Res 12:5454-5463

106. Cole SP (1986) Rapid chemosensitivity testing of human lung tumor cells using the MTT assay. Cancer Chemother Pharmacol $17: 259-263$

107. Kurbacher CM, Cree IA, Bruckner HW, Brenne U, Kurbacher JA, Müller K, Ackermann T, Gilster TJ, Wilhelm LM, Engel H, Mallmann PK, Andreotti PE (1998) Use of an ex vivo ATP luminescence assay to direct chemotherapy for recurrent ovarian cancer. Anticancer Drugs 9(1):51-57

108. Mosmann T (1983) Rapid colorimetric assay for cellular growth and survival: Application to proliferation and cytotoxicity assays. J Immunol Methods 65(1-2):55-63

109. Larsson R, Nygren P, Ekberg M, Slater L (1990) Chemotherapeutic drug sensitivity testing of human leukemia cells in vitro using a semiautomated fluorometric assay. Leukemia 4:567-571

110. Kangas L, Grönroos M, Nieminen AL (1984) Bioluminescence of cellular ATP: a new method for evaluating agents in vitro. Med Biol 62:338-343

111. Ahmann FR, Garewal HS, Schifman R, Celniker A, Rodney S (1987) Intracellular adenosine triphosphate as a measure of human tumor cell viability and drug modulated growth. Vitro Cell Dev Biol 23(7):474-480

112. Voigt W (2005) Sulforhodamine B assay and chemosensitivity. Methods Mol Med 110:39-48

113. Vichai V, Kirtikara K (2006) Sulforhodamine B colorimetric assay for cytotoxicity screening. Nat Protoc 1:1112-1116

114. Kubota T, Takahara T, Nagata M, Furukawa T, Kase S, Tanino H, Ishibiki K, Kitajima M (1993) Colorimetric chemosensitivity testing using sulforhodamine B. J Surg Oncol 52:83-88

115. Boyd MR (1990) Status of the NCI preclinical antitumor drug discovery screen, implications for selection of new agents for clinical trial in cancer. Principles and practice of oncology updates. Lippincott, Philadelphia

116. Kurbacher CM, Grecu OM, Stier U, Gilster TJ, Janat MM, Untch M, Konecny G, Bruckner HW, Cree IA (2003) ATP chemosensitivity testing in ovarian and breast cancer: early clinical trials. Recent Results Cancer Res 161:221-230

117. Quartino A, Karlsson MO, Freijs A, Jonsson N, Nygren P, Kristensen J, Lindhagen E, Larsson R (2007) Modeling of in vitro drug activity and prediction of clinical outcome in acute myeloid leukemia. J Clin Pharmacol 47:1014-1021

118. Yanagawa E, Nishiyama M, Saeki T, Kim R, Jinushi K, Kirihara Y, Takagami S, Niimoto M, Hattori T (1989) Chemosensitivity tests in colorectal cancer patients. Jpn J Surg 19:432-438

119. Moon YW, Choi SH, Kim YT, Sohn JH, Chang J, Kim SK, Park MS, Chung KY, Lee HJ, Kim JH (2007) Adenosine triphosphate-based chemotherapy response assay (ATP-CRA)-guided 
platinum-based 2-drug chemotherapy for unresectable nonsmallcell lung cancer. Cancer 109:1829-1835

120. Kim JH, Lee KW, Kim YH, Lee KH, Oh do Y, Kim J, Yang SH, Im SA, Choi SH, Bang YJ (2010) Individualized tumor response testing for prediction of response to Paclitaxel and Cisplatin chemotherapy in patients with advanced gastric cancer. J Korean Med Sci 25:684-690

121. Konecny G, Uncht M, Slamon D, Beryt M, Kahlert S, Felber M, Langner E, Lude S, Hepp H, Pegram M (2001) Drug interactions and cytotoxic effects of paclitaxel in combination with carboplatin epirubicin gemcitabine or vinorelbine in breast cancer cell lines and tumor samples. Breast Cancer Res Treatm 67:223-233

122. Giovannetti E, Mey V, Nannizzi S, Pasqualetti G, Marini L, Del Tacca M, Danesi R (2005) Cellular and pharmacogenetics foundation of synergistic interaction of pemetrexed and gemcitabine in human non-small-cell lung cancer cells. Mol Pharmacol 68:110-118

123. Jekunen AP, Christen RD, Shalinsky DR, Howell SB (1994) Synergistic interaction between cisplatin and taxol in human ovarian carcinoma cells in vitro. Br J Cancer 69:299-306

124. Yunos NM, Beale P, Yu JQ, Strain D, Huq F (2010) Studies on combinations of platinum with Paclitaxel and colchicines in ovarian cancer cell lines. Anticancer Res 30:4025-4037

125. Cree IA (2009) Chemosensitivity and chemoresistance testing in ovarian cancer. Curr Opin Obstet Gynecol 21:39-43

126. Courtnay VD, Selby PJ, Smith IE, Mills J, Peckham MJ (1987) Growth of human tumor cell colonies from biopsies using two soft-agar techniques. Brit J Cancer 38:77-81

127. Hatok J, Babusikova E, Matakova T, Mistuna D, Dobrota D, Racay P (2009) In vitro assays for evaluation of drug resistance in tumor cells. Clin Exp Med 9:1-7

128. Schrag D, Garewal HS, Burstein HJ, Samson DJ, von Hoff DD, Somerfield MR (2004) American Society of Clinical Oncology technology assessment: chemotherapy sensitivity and resistance assays. J Clin Oncol 22:3631-3638

129. Frühauf JP, Alberts DS (2005) In vitro drug resistance versus chemosensitivity: two sides of different coins. J Clin Oncol 23:3641-3643

130. Nagourney R (2005) Chemosensitivity and resistance assays: a systematic review? J Clin Oncol 23:3640-3641

131. Fruehauf JP, Bosanquet AG (1993) In vitro determination of drug response: a discussion of clinical applications. In: DeVita VT Jr, Hellman S, Rosenberg SA (eds) Cancer: principles and practices of oncology. J B Lippincott Co, Philadelphia, pp 1-16

132. Bellamy WT (1992) Prediction of response to drug therapy of cancer: a review of in vitro assays. Drugs 44:690-708

133. Von Hoff DD, Kronmal R, Salmon SE, Turner J, Green JB, Bonorris JS, Moorhead EL, Hynes HE, Pugh RE, Belt RJ, Alberts DS (1991) A Southwest Oncology Group study on the use of a human tumor cloning assay for predicting response in patients with ovarian cancer. Cancer 67:20-27

134. Weisenthal LM, Kern DH (1991) Prediction of drug resistance in cancer chemotherapy: the Kern and DiSC assays. Oncology 5:93-103

135. Leone LA, Meitner PA, Myers TJ, Grace WR, Gajewski WH, Fingert HJ, Rotman B (1991) Predictive value of the fluorescent cytoprintassay (FCA): a retrospective correlation study of in vitro chemosensitivity and individual responses to chemotherapy. Cancer Invest 9:491-503

136. Sevin BU, Perras JP, Averette HE, Donato DM, Penalver M (1993) Chemosensitivity testing in ovarian cancer. Cancer 71:1613-1620

137. Kopjar N, Garaj-Vrhovac V, Milas I (2002) Assessment of chemotherapy-induced DNA damage in peripheral blood leukocytes of cancer patients using the alkaline comet assay. Terat Carc Mutag 22(1):13-30
138. Bosken CH, Wei Q, Amos CI, Spitz MR (2002) An analysis of DNA repair as a determinant of survival in patients with nonsmall-cell lung cancer. J Natl Cancer Inst 94:1091-1099

139. Nadin SB, Vargas-Roig LM, Drago G, Ibarra J, Ciocca DR (2006) DNA damage and repair in peripheral blood lymphocytes from healthy individuals and cancer patients: a pilot study on the implications in the clinical response to chemotherapy. Cancer Lett 239:84-97

140. Unger FT, Klasen HA, Tchartchian G, de Wilde RL, Witte I (2009) DNA damage induced by cis- and carboplatin as indicator for in vitro sensitivity of ovarian carcinoma cells. BMC Cancer 9:359-368

141. Reed E, Ozols RF, Tarone R, Yuspa SH, Poirier MC (1987) Platinum-DNA adducts in leukocyte DNA correlate with disease response in ovarian cancer patients receiving platinum-based chemotherapy. Proc Natl Acad Sci USA 84:5024-5028

142. Rabik CA, Dolan ME (2007) Molecular mechanisms of resistance and toxicity associated with platinating agents. Cancer Treat Rev 33:9-23

143. Müller MR, Buschfort C, Thomale J, Lensing C, Rajewsky MF, Seeber S (1997) DNA repair and cellular resistance to alkylating agents in chronic lymphocytic leukemia. Clin Cancer Res 3:2055-2061

144. Almeida GM, Duarte TL, Farmer PB, Steward WP, Jones GD (2008) Multiple end-point analysis reveals cisplatin damage tolerance to be a chemoresistance mechanism in a NSCLC model: implications for predictive testing. Int J Cancer 122:1810-1819

145. Teodoridis JM, Hall J, Marsh S, Kannall HD, Smyth C, Curto J, Siddiqui N, Gabra H, McLeod HL, Strathdee G, Brown R (2005) $\mathrm{CpG}$ island methylation of DNA damage response genes in advanced ovarian cancer. Cancer Res 65(19):896

146. Wade Harper J, Elledge SJ (2007) The DNA damage response: 10 years after. Mol Cell 28:739-745

147. O'Connor MJ, Martin NMB, Smith GCM (2007) Targeted cancer therapies based on the inhibition of DNA strand break repair. Oncogene 26:781624

148. Ashwell S, Zabludoff S (2008) DNA damage detection and repair pathways recent advances with inhibitors of checkpoint kinases in cancer therapy. Clin Cancer Res 14:4032-4037

149. Norbury CJ, Zhivotovsky B (2004) DNA damage-induced apoptosis. Oncogene 23:2797-2808

150. Roosa WP, Kaina B (2006) DNA damage-induced cell death by apoptosis. Trends Mol Med 12(9):440-450

151. Wieder R (2005) TUNEL assay as a measurwe of chemotherapy-induced apoptosis. Meth Mol Med 111:43-52

152. Gercel-Taylor C (2005) Diphenylamine assay of DNA fragmentation for chemosensitivity testing. Methods Mol Med 111:79-82

153. Vermes I, Haanen C, Reutelingsperger C (2005) Flow cytometry of apoptotic cell death. J Immun Methods 243:167-190

154. Schutters K, Reutelingsperger C (2010) Phosphatidylserine targeting for diagnosis and treatment of human diseases. Apoptosis 15:1072-1082

155. Slee EA, Harte MT, Kluck RM, Wolf BB, Casiano CA, Newmeyer DD, Wang HG, Reed JC, Nicholson DW, Alnemri ES, Green DR, Martin SJ (1999) Ordering the Cytochrome c initiated Caspase Cascade: Hierarchical Activation of Caspases-2 -3 $-6-7-8$ and -10 in a Caspase- 9 dependent Manner. J Cell Biol 144:281-292

156. Dive C, Hickman JA (1991) Drug-target interactions: only the first step in the commitment to a programmed cell death? Br J Cancer 64(192): 196

157. Zhao M, Beauregard DA, Loizou L, Davletov B, Brindle KM (2001) Non-invasive detection of apoptosis using magnetic resonance imaging and a targeted contrast agent. Nat Med 7:1241-1244 
158. Kojima H, Endo K, Moriyama H, Tanaka Y, Alnemrii ES, Slapak CA, Teicher B, Kufe D, Datta R (1998) Abrogation of mitochondrial cytochrome $\mathrm{c}$ release and caspase-3 activation in acquired multidrug resistance. J Biol Chem 273(27):16647-16650

159. Eggert A, Grotzer MA, Zuzak TJ, Wiewrodt BR, Ho R, Ikegaki N, Brodeur GM (2001) Resistance to tumor necrosis factorrelated apoptosis-inducing ligand-induced apoptosis in neuroblastoma cells correlates with a loss of caspase-8 expression1. Cancer Res 61:1314-1319

160. Hakem R, Hakem A, Duncan GS (1998) Differential requirement for caspase 9 in apoptotic pathways in vivo. Cell 94:339-352

161. Yoshida H, Kong YY, Yoshida R (1998) Apaf1 is required for mitochondrial pathways of apoptosis and brain development. Cell 94:739-750

162. Bandoh N, Hayashi T, Kishibe K, Takahara M, Imada M, Nonaka S, Harabuchi Y (2002) Prognostic value of p53 mutations bax and spontaneous apoptosis in maxillary sinus squamous cell carcinoma. Cancer 94:1968-1980

163. Jain D, Srinivasan R, Patel FD, Kumari Gupta S (2003) Evaluation of p53 and Bcl-2 expression as prognostic markers in invasive cervical carcinoma stage IIb/III patients treated by radiotherapy. Gynecol Oncol 88:22-28

164. Hanahan D, Weinberg RA (2000) The hallmarks of cancer. Cell 100:57-70

165. Hunter T (2000) Signaling-2000 and beyond. Cell 100:113-127

166. Fearon ER, Vogelstein B (1990) A genetic model for colorectal tumorigenesis. Cell 61:759-767

167. Bhattacharjee A, Richards WG, Staunton J, Li C, Monti S, Vasa P, Ladd C, Beheshti J, Bueno R, Gillette M (2001) Classification of human lung carcinomas by mRNA expression profiling reveals distinct adenocarcinoma subclasses. Proc Natl Acad Sci USA 98:13790-13795

168. Golub TR, Slonim DK, Tamayo P, Huard C, Gaasenbeek M, Mesirov JP (1999) Molecular classification of cancer: class discovery and class prediction by gene expression monitoring. Science 286(5439):531-537

169. Nevins JR, Huang ES, Dressman H, Pittman J, Huang AT, West M (2003) Towards integrated clinico-genomic models for personalized medicine: combining gene expression signatures and clinical factors in breast cancer outcomes prediction. Hum Mol Genet 12:R153-R157

170. Ross JS, Hatzis C, Fraser Symanns W, Pusztai L, Hortobágyi GN (2008) Commercialized multigene predictors of clinical outcome for breast cancer. Oncologist 13:477-493

171. Ekong R, Wolfe J (1998) Advances in fluorescent in situ hybridisation. Curr Opin Biotechnol 9:19-24

172. Volpi EV, Bridger JM (2008) FISH glossary: an overview of the fluorescence in situ hybridization technique. BioTechniques 45:385-409

173. Levsky JM, Singer RH (2003) Fluorescence in situ hybridization: past present and future. J Cell Sci 116:2833-2838

174. Hopman AHN, Wiegant J, Raap AK, Landegent JE, Ploeg M, Duijn P (1986) Bi-color detection of two target DNAs by nonradioactive in situ hybridization. Histochem Cell Biol 85(1):1-4

175. Nederlof PM, Robinson D, Abuknesha R, Wiegant J, Hopman AHN, Tanke HJ, Raap AK (1989) Three-color fluorescence in situ hybridization for the simultaneous detection of multiple nucleic acid sequences. Cytometry 10:20-27

176. Yoshimoto M, Joshua AM, Chilton-MacNeill S, Bayani J, Selvarajah S, Evans AJ, Zielenska M, Squire JA (2006) Threecolor FISH analysis of TMPRSS2/ERG fusions in prostate cancer indicates that genomic microdeletion of chromosome 21 is associated with rearrangement. Neoplasia 8(6):465-469
177. Nederlof PM, van der Flier S, Wiegant J, Raap AK, Tanke HJ, Pleom JS, van der Ploeg M (1990) Multiple fluorescence in situ hybridization. Cytometry 11(1):126-131

178. Chudoba I, Plesch A, Lörch T, Lemke J, Claussen U, Sengera G (1999) High resolution multicolor-banding: a new technique for refined FISH analysis of human chromosomes. Cytogenet Cell Genet 84(3-4):156-160

179. Wiegant J, Bezrookove V, Rosenberg C, Tanke HJ, Raap AK, Zhang H, Bittner M, Trent JM, Meltzer P (2000) Differentially painting human chromosome arms with combined binary ratiolabeling fluorescence in situ hybridization. Genome Res 10:861-865

180. Perez EA, Suman VJ, Davidson NE, Martino S, Kaufman PA, Lingle WL, Flynn PJ, Ingle JN, Visscher D, Jenkins RB (2006) HER2 testing by local central and reference laboratories in specimens from the north central cancer treatment group N9831 intergroup adjuvant trial. J Clin Oncol 24(19):3032

181. Bartlett JMS, Ellis IO, Dowsett M, Mallon EA, Cameron DA, Johnston S, Hall E, A'Hern R, Peckitt C, Bliss JM, Johnson L, Barrett-Lee P, Ellis P (2007) Human epidermal growth factor receptor 2 status correlates with lymph node involvement in patients with estrogen receptor (ER) - negative, but with grade in those with ER-positive early-stage breast cancer suitable for cytotoxic chemotherapy. J Clin Oncol 25(28)

182. Robert N, Leyland-Jones B, Asmar L, Belt R, Ilegbodu D, Loesch D, Raju R, Valentine E, Sayre R, Cobleigh MA, Albain K, McCullough C, Fuchs L, Slamon D (2006) Randomized phase III study of trastuzumab paclitaxel and carboplatin compared with trastuzumab and paclitaxel in women with HER-2-overexpressing metastatic breast cancer. J Clin Oncol 24(18)

183. Vogel CL, Cobleigh MA, Tripathy D, Gutheil JC, Harris LN, Fehrenbacher L, Slamon DJ, Murphy M, Novotny WF, Burchmore M, Shak S, Stewart SJ, Press M (2002) Efficacy and safety of trastuzumab as a single agent in first-line treatment of HER2overexpressing metastatic breast cancer. J Clin Oncol 20(3):719-726

184. Jhawer M, Goel S, Wilson AJ, Montagna C, Ling YH, Byun DS, Nasser S, Arango D, Shin J, Klampfer L, Augenlicht LH, Perez Soler R, Mariadason JM (2008) PIK3CA mutation/PTEN expression status predicts response of colon cancer cells to the epidermal growth factor receptor inhibitor cetuximab. Cancer Res 68(6): 1953

185. Hirsch FR, Varella-Garcia M, Bunn PA Jr, Di Maria MV, Veve R, Bremnes RM, Baro AE, Zeng C, Franklin WA (2003) Epidermal growth factor receptor in non-small-cell lung carcinomas: correlation between gene copy number and protein expression and impact on prognosis. J Clin Oncol 21(20):3798-3807

186. Ross JS, Symmans WF, Pusztai L (2007) Standardizing slidebased assays in breast cancer: Hormone receptors HER 2 and sentinel lymph nodes. Clin Cancer Res 13:2831-2835

187. Sanger F, Nicklen S, Coulson AR (1977) DNA sequencing with chain-terminating inhibitors. Proc Natl Acad Sci USA 74:5463-5467

188. Shendure J, Ji H (2008) Next-generation DNA sequencing. Nat Biotechnol 26:1135-1145

189. Margulies M, Egholm M, Altman WE, Attiya S, Bader JS, Bemben LA, Berka J, Braverman MS, Chen YJ, Chen Z, Dewell SB, Du L, Fierro JM, Gomes XV, Goodwin BC, He W, Helgesen S, Ho CH, Irzyk GP, Jando SC, Alenquer MLI, Jarvie TP, Jirage KB, Kim JB, Knight JR, Lanza JR, Leamon JH, Lefkowitz SM, Lei M, Li J, Lohman KL, Lu H, Makhijani VB, McDade KE, McKenna MP, Myers EW, Nickerson E, Nobile JR, Plant R, Puc BP, Ronan MT, Roth GT, Sarkis GJ, Simons JF, Simpson JW, Srinivasan M, Tartaro KR, Tomasz A, Vogt KA, Volkmer GA, Wang SH, Wang Y, Weiner MP, Yu P, Begley RF, Rothberg JM (2005) Genome sequencing in open 
microfabricated high density picoliter reactors. Nature 437(7057):376-380

190. Wheeler DA, Srinivasan M, Egholm M, Shen Y, Chen L, McGuire A, He W, Chen Y, Makhijani V, Roth GT, Gomes X, Tartaro K, Niazi F, Turcotte CL, Irzyk GP, Lupski JR, Chinault C, Song X, Liu Y, Yuan Y, Nazareth L, Qin X, Muzny DM, Margulies M, Weinstock GM, Gibbs RA, Rothberg JM (2008) The complete genome of an individual by massively parallel DNA sequencing. Nature 452:872-876

191. Shendure J, Porreca GJ, Reppas NK, Lin X, McCutcheon JP, Rosenbaum AM, Wang MD, Zhang K, Mitra RD, Church GM (2005) Accurate multiplex polony sequencing of an evolved bacterial genome. Science 309:1728-1732

192. Swanton C, Szallasi Z, Brenton JD, Downward J (2008) Functional genomic analysis of drug sensitivity pathways to guide adjuvant strategies in breast cancer. Breast Cancer Research $10: 214$

193. Lima JJ, Thomason DB, Mohamed MH, Eberle LV, Self TH, Johnson JA (1999) Impact of genetic polymorphisms of the bold beta2-adrenergic receptor on albuterol bronchodilator pharmacodynamics. Clin Pharmacol Ther 65:519-525

194. Roden DM, George AL Jr (2002) The genetic basis of variability in drug responses. Nature Rev Drug Discov 1:37-44

195. Park J, Han S, Cho Y, Paik WK, Kim YB, Lim IK (2001) Methylation of O6-methylguanine-DNA methyltransferase gene is associated significantly with K-ras mutation lymph node invasion tumor staging and disease free survival in patients with gastric carcinoma. Cancer 92(11):2760-2768

196. Paik H, Lee E, Lee D (2010) Relationships between genetic polymorphisms and transcriptional profiles for outcome prediction in anticancer agent treatment. BMB Rep 43(12):836

197. Gamazona ER, Huang RS, Coxa NJ, Dolan ME (2010) Chemotherapeutic drug susceptibility associated SNPs are enriched in expression quantitative trait loci. Proc Natl Acad Sci USA 107(20):9287-9292

198. Huang RS, Duan S, Shukla SJ, Kistner EO, Clark TA, Chen TX, Schweitzer AC, Blume JE, Dolan ME (2007) Identification of genetic variants contributing to cisplatin-induced cytotoxicity by use of a genomewide. Am J Hum Genet 81:427-437

199. Kim JC, Kim SY, Cho DH, Roh SA, Choi EY, Jo YK, Jung SH, Na YS, Kim TW, Kim YS (2010) Genome-wide identification of chemo-sensitive single nucleotide polymorphism markers in colorectal cancers. Cancer Sci 101(4):1007-1013

200. Ikediobi ON, Davies H, Bignell G, Edkins S, Stevens C, O'Meara S, Santarius T, Avis T, Barthorpe S, Brackenbury L, Buck G, Butler A, Clements J, Cole J, Dicks E, Forbes S, Gray K, Halliday K, Harrison R, Hills K, Hinton J, Hunter C, Jenkinson A, Jones D, Kosmidou V, Lugg R, Menzies A, Mironenko T, Parker A, Perry J, Raine K, Richardson D, Shepherd R, Small A, Smith R, Solomon H, Stephens P, Teague J, Tofts C, Varian J, Webb T, West S, Widaa S, Yates A, Reinhold W, Weinstein JN, Stratton MR, Futreal P, Wooster R (2006) Mutation analysis of 24 known cancer genes in the NCI60 cell line set. Mol Cancer Ther 5(11):2606

201. Eng L, Ibrahim-zada I, Jarjanazi H, Savas S, Meschian M, Pritchard KI, Ozcelik H (2011) Bioinformatic analysis identifies novel proteincoding pharmacogenomic markers associated with paclitaxel sensitivity in NCI60 cancer cell lines. BMC Med Genomics 418

202. Savas S, Briollais L, Ibrahim-zada I, Jarjanazi H, Choi YH (2010) A whole-genome SNP Association Study of NCI60 cell line panel indicates a role of $\mathrm{Ca} 2+$ signaling in selenium resistance. PLoS One 5(9):e12601

203. Robert J, Le Morvan V, Smith D, Pourquier P, Bonnet J (2005) Predicting drug response and toxicity based on gene polymorphisms. Crit Rev Oncol Hematol 54:171-196
204. Sauna ZE, Kimchi-Sarfaty C, Ambudkar SV, Gottesman MM (2007) Silent polymorphisms speak: how they affect pharmacogenomics and the treatment of cancer. Cancer Res 67(20):9609

205. Paull K, Shoemaker R, Hodes L (1989) Display and analysis of patterns of differential activity of drugs against human tumor cell lines: development of mean graph and COMPARE algorithm. J Natl Cancer Inst 81:1088-1092

206. Weinstein JN, Kohn KW, Grever MR (1992) Neural computingin cancer drug development: predicting mechanism of action. Science 258:447-451

207. Weinstein JN, Myers TG, O'Connor PM, Friend SH, Fornace AJ Jr, Kohn KW, Fojo T, Bates SE, Rubinstein LV, Anderson NG, Buolamwini JK, van Osdol WW, Monks AP, Scudiero DA, Sausville EA, Zaharevitz DW, Bunow B, Viswanadhan VN, Johnson GS, Wittes RE, Paull KD (1997) An informationintensive approach to the molecular pharmacology of cancer. Science 275(5298):343-349

208. O'Connor PM, Jackman J, Bae I, Myers TG, Fan S, Mutoh M, Scudiero DA, Monks A, Sausville EA, Weinstein JN, Friend S, Fornace AJ Jr, Kohn KW (1997) Characterization of the p53 tumor suppressor pathway in cell lines of the National Cancer Institute Anticancer Drug Screen and Correlations with the growth-inhibitory potency of 123 anticancer agents. Cancer Res 57:4285-4300

209. Huang Y, Anderle P, Bussey KJ, Barbacioru C, Shankavaram U, Dai Z, Reinhold WC, Papp A, Weinstein JN, Sade W (2004) Membrane transporters and channels: role of the transportome in cancer chemosensitivity and chemoresistance. Cancer Res 64:4294-4301

210. Fitzsimmons SA, Workman P, Grever M, Paull K, Camalier R, Lewis AD (1996) Reductase enzyme expression across the National Cancer Institute Tumor Cell Line Panel: correlation with sensitivity to mitomycin C and EO9. J Natl Cancer Inst 88(5):259-269

211. Liu W, Wu X, Zhang W, Montenegro RC, Fackenthal DL, Spitz JA, Mickley Huff L, Innocenti F, Das S, Cook EH Jr, Cox NJ, Bates SE, Ratain MJ (2007) Relationship of EGFR mutations expression amplification and polymorphisms to epidermal growth factor receptor inhibitors in the NCI60 cell lines. Clin Cancer Res 13(22):6788-6795

212. Yu LJ, Matias J, Scudiero DA, Hite KM, Monks A, Sausville EA, Waxman DJ (2001) P450 enzyme expression patterns in the nci human tumor cell line panel. Drug Metab Dispos 29(3):304-312

213. Alvarez M, Robey R, Sandor V, Nishiyama K, Matsumoto Y, Paull K, Bates S, Fojo T (2008) Using the National Cancer Institute Anticancer Drug Screen to assess the effect of MRP expression on drug SENSITIVITY profiles. Mol Pharmacol $54: 802-814$

214. Staunton JE, Slonim DK, Coller HA, Tamayo P, Angelo MJ, Park J, Scherf U, Lee JK, Reinhold WO, Weinstein JN, Mesirov JP, Lander ES, Golub TR (2001) Chemosensitivity prediction by transcriptional profiling. Proc Natl Acad Sci USA 98(19): 10787-10792

215. Scherf U, Ross DT, Waltham M, Smith LH, Lee JK, Tanabe L, Kohn KW, Reinhold WC, Myers TG, Andrews DT, Scudiero DA, Eisen MB, Sausville EA, Pommier Y, Botstein D, Brown PO, Weinstein JN (2000) A gene expression database for the molecular pharmacology of cancer. Nature Genet 24:236-244

216. Amundson SA, Myers TG, Scudiero D, Kitada S, Reed JC, Fornace AJ Jr (2000) An informatics approach identifying markers of chemosensitivity in human cancer cell lines. Cancer Res 60:6101-6110

217. Lee JK, Havaleshko DM, Cho H, Weinstein JN, Kaldjian EP, Karpovich J, Grimshaw A, Theodorescu D (2007) A strategy for predicting the chemosensitivity of human cancers and its 
application to drug discovery. Proc Natl Acad Sci USA 104(32):13086-13091

218. Dan S, Shirakawa M, Mukai Y, Yoshida Y, Yamazaki K, Kawaguchi T, Matsuura M, Nakamura Y, Yamori T (2003) Identification of candidate predictive markers of anticancer drug sensitivity using a panel of human cancer cell lines. Cancer Sci 94:1074-1082

219. Nakatsu N, Yoshida Y, Yamazaki K, Nakamura T, Dan S, Fukui Y, Yamori T (2005) Chemosensitivity profile of cancer cell lines and identification of genes determining chemosensitivity by an integrated bioinformatical approach using cDNA arrays. Mol Cancer Ther 4(3):399-412

220. Györffy B, Surowiak P, Kiesslich O, Denkert C, Schäfer R, Dietel M, Lage H (2006) Gene expression profiling of 30 cancer cell lines predicts resistance towards 11 anticancer drugs at clinically achieved concentrations. Int J Cancer 118:1699-1712

221. Sekine I, Minna JD, Nishio K, Saijo N, Tamura T (2007) Genes regulating the sensitivity of solid tumor cell lines to cytotoxic agents: a literature review. Jpn J Clin Oncol 37(5):329-336

222. Whiteford CC, Bilke S, Greer BT, Chen Q, Braunschweig TA, Cenacchi N, Wei JS, Smith MA, Houghton P, Morton C, Reynolds CP, Lock R, Gorlick R, Khanna C, Thiele CJ, Takikita M, Catchpoole D, Hewitt SM, Khan J (2007) Credentialing preclinical pediatric xenograft models using gene Expression and tissue microarray analysis. Cancer Res 67(1):32-40

223. Zembutsu H, Ohnishi Y, Tsunoda T, Furukawa Y, Katagiri T, Ueyama Y (2002) Genome-wide cDNA microaray screening to correlate gene expression profiles with sensitivity of 85 human cancer xenografts to anticancer drugs. Cancer Res 62:518-527

224. Braun MJ, Richman SD, Quirke P, Daly C, Adlard JW, Elliott F, Barrett JH, Selby P, Meade AM, Stephens RJ, Parmar MKB, Seymour MT (2008) Predictive biomarkers of chemotherapy efficacy in colorectal cancer: results from the UK MRC FOCUS Trial. J Clin Oncol 26:2690-2698

225. Matsuyama R, Togo S, Shimizu D, Momiyama N, Ishikawa T, Ichikawa Y, Endo I, Kunisaki C, Suzuki H, Hayasizaki Y, Shimada H (2006) Predicting 5-fluorouracil chemosensitivity of liver metastases from colorectal cancer using primary tumor specimens: Three-gene expression model predicts clinical response. Int J Cancer 119:406-413

226. Kihara C, Tsunoda T, Tanaka T, Yamana H, Furukawa Y, Ono K (2001) Prediction of sensitivity of esophageal tumors to adjuvant chemotherapy by cDNA microarray analysis of geneexpression profiles. Cancer Res 61:6474-6479

227. Naniwa J, Kigawa J, Kanamori Y, Itamochi H, Oishi T, Shimada M, Shimogai R, Kawaguchi W, Sato S, Terakawa N (2007) Genetic diagnosis for chemosensitivity with drug-resistance genes in epithelial ovarian cancer. Int J Gynecol Cancer 17:76-82

228. Michalski CW, Erkan M, Sauliunaite D, Giese T, Stratmann R, Sartori C, Giese NA, Friess H, Kleeff DJ (2008) Ex vivo chemosensitivity testing and gene expression profiling predict response towards adjuvant gemcitabine treatment in pancreatic cancer. Br J Cancer 99:760-767

229. Iwao-Koizumi K, Matoba R, Ueno N, Kim SJ, Ando A, Miyoshi Y, Maeda E, Noguchi S, Kato K (2005) Prediction of docetaxel response in Human breast cancer by gene expression profiling. J Clin Oncol 23(3):422-431

230. Gianni L, Zambetti M, Clark K, Baker J, Cronin M, Wu J, Mariani G, Rodriguez J, Carcangiu M, Watson D, Valagussa P, Rouzier R, Symmans WF, Ross JS, Hortobagyi GN, Pusztai L, Shak S (2005) Gene expression profiles in paraffin-embedded core biopsy tissue predict response to chemotherapy in women with locally advanced breast cancer. J Clin Oncol 23(29):7265-7277

231. Brenton JD, Carey LA, Ahmed AA, Caldas C (2005) Molecular classification and molecular forecasting of breast cancer: ready for clinical application? J Clin Oncol 23:7350-7360
232. Ahmed AA, Brenton JD (2005) Microarrays and breast cancer clinical studies: forgetting what we have not yet learnt. Breast Cancer Res 7:96-99

233. Ein-Dor L, Zuk O, Domany E (2006) Thousands of samples are needed to generate a robust gene list for predicting outcome in cancer. Proc Natl Acad Sci USA 103:5923-5928

234. Sørlie T, Perou CM, Fan C, Geisler S, Aas T, Nobel A, Anker G, Akslen LA, Botstein D, Børresen-Dale AL, Lønning PE (2006) Gene expression profiles do not consistently predict the clinical treatment response in locally advanced breast cancer. Mol Cancer Ther 5:2914-2918

235. Symmans WF, Ayers M, Clark EA (2003) Total RNA yield and microarray gene expression profiles from fine-needle aspiration biopsy and core needle biopsy samples of breast carcinoma. Cancer 97:2960-2971

236. Buyse M, Loi S, van't Veer L (2006) TRANSBIG consortium validation and clinical utility of a 70-gene prognostic signature for women with nodenegative breast cancer. J Natl Cancer Inst 98:1183-1189

237. Paik S, Tang G, Shak S (2006) Gene expression and benefit of chemotherapy in women with node-negative estrogen receptorpositive breast cancer. J Clin Oncol 24:3726-3734

238. Ayers M, Symmans WF, Stec J (2004) Gene expression profiles predict complete pathologic response to neoadjuvant paclitaxel and fluorouracil doxorubicin and cyclophosphamide chemotherapy in breast cancer. J Clin Oncol 22:2284-2293

239. Anderson L, Seilhamer JA (1997) comparison of selected mRNA and protein abundances in human liver. Electrophoresis 18:533-537

240. Chen G, Gharib TG, Huang C, Taylor JMG, Misek DE, Kardia SLR, Giordano TJ, Iannettoni MD, Orringer MB, Hanash SM, Beer DG (2002) Discordant protein and mRNA expression in lung adenocarcinomas. Mol Cel Proteomics 1:304-313

241. Wulfkuhle JD, Speer R, Pierobon M, Laird J, Espina V, Deng J, Mammano E, Yang SX, Swain SM, Nitti D, Esserman LJ, Belluco C, Liotta LA, Petricoin EF (2008) Multiplexed cell signaling analysis of human breast cancer applications for personalized therapy. J Proteome Res 7:1508-1517

242. Somiari RI, Sullivan A, Russell S, Somiari S, Hu H, Jordan R, George A, Katenhusen R, Buchowiecka A, Arciero C, Brzeski H, Hooke J, Shriver C (2003) High-throughput proteomic analysis of human infiltrating ductal carcinoma of the breast. Proteomics 3(10):1863-1873

243. Lage H (2009) Proteomic approaches for investigation of therapy resistance in cancer. Proteomics Clin Appl 3:883-911

244. Michener CM, Ardekani AM, Petricoin EF (2002) Genomics and proteomics: application of novel technology to early detection and prevention of cancer. Cancer Detect Prev 26:249-255

245. Gorg A, Obermaier C, Boguth G (2000) The current state of twodimensional electrophoresis with immobilized $\mathrm{pH}$ gradients. Electrophoresis 21:1037-1053

246. Hanash SM (2000) Biomedical applications of two-dimensional electrophoresis using immobilized $\mathrm{pH}$ gradients: current status. Electrophoresis 21:1202-1209

247. Posadas EM, Simpkins F, Liotta LA, MacDonald C, Kohn EC (2005) Proteomic analysis for the early detection and rational treatment of cancer-realistic hope? Ann Oncol 16:16-22

248. Latterich M, Abramovitz M, Leyland-Jones B (2008) Proteomics: new technologies and clinical applications. Eur J Cancer 44:2737-2741

249. Panchaud A, Affolter M, Moreillon P, Kussmann M (2008) Experimental and computational approaches to quantitative proteomics: status quo and outlook. J Proteomics 71:19-33

250. Wouters BG (2008) Proteomics: methodologies and applications in oncology. Semin Radiat Oncol 18:115-125 
251. Somiaria RI, Somiarib S, Russella S, Shriver CD (2005) Proteomics of breast carcinoma. J Chromatogr B 815:215-225

252. Steiner S, Witzmann FA (2000) Proteomics: applications and opportunities in preclinical drug development. Electrophoresis 21(11):2099-2104

253. Celisa JE, Kruhøffer M, Frederiksen C, Østergaard M, Thykjaer T, Gromova P, Yub J, Pálsdóttir H, Magnusson N, Ørntoft TF (2000) Gene expression profiling: monitoring transcription and translation products using DNA microarrays and proteomics. FEBS Lett 480:2-16

254. O'Farrel PH (1975) High-resolution two dimensional electrophoresis of proteins. J BiolChem 250:4007-4021

255. Rai AJ, Chan DW (2004) Cancer proteomics: Serum diagnostics for tumor marker discovery. Ann N Y Acad Sci 1022:286-294

256. Van den Bergh G, Arckens L (2005) Recent advances in 2D electrophoresis: an array of possibilities. Expert Rev Proteomics 2:243-252

257. Haleem J, Veenstra I, Veenstra TD (2008) Two-dimensional polyacrylamide gel electrophoresis (2D-PAGE): advances and perspectives. BioTechniques 44:697-700

258. Zhang YT, Geng Y, Zhou L, Lai B, Si L, Wang Y (2005) Identification of proteins of human colorectal carcinoma cell line SW480 by two-dimensional electrophoresis and MALDITOF mass spectrometry. World J Gastroenterol 11(30): 4679-4684

259. Qu L, Ding Y, Liang L (2005) Differential proteomic analysis of human colorectal carcinoma cell lines SW620 and SW480 with different metastatic potentials. J First Mil Med Univ 25(10): $1211-1220$

260. Friedman DB, Hill S, Keller JW, Merchant NB, Levy SE, Coffey RJ, Caprioli RM (2004) Proteome analysis of human colon cancer by two-dimensional difference gel electrophoresis and mass spectrometry. Proteomics 4:793-811

261. Chuthapisith S, Layfield R, Kerr ID, Hughes C, Eremin O (2007) Proteomic profiling of MCF-7 breast cancer cells with chemoresistance to different types of anti-cancer drugs. Int $\mathbf{J}$ Oncol 30:1545-1551

262. Shen DW, Cardarelli C, Hwang J (1986) Multiple drug-resistant human KB carcinoma cells independently selected for high level resistance to colchicine adriamycin or vinblastine show changes in expression of specific proteins. J Biol Chem 261:7762-7770

263. Khoudoli GA, Porter IM, Blow JJ, Swedlow JR (2004) Optimisation of the two-dimensional gel electrophoresis protocol using the Taguchi approach. Proteome Sci 2:6

264. Onga S, Pandey A (2001) An evaluation of the use of twodimensional gel electrophoresis in proteomics. Biomol Eng 18(5):195-205

265. Tanaka S, Sakai A, Kimura K, Yoshida H, Fushitani H, Ogata A, Miyamoto A, Fukushima M, Wada A, Tanigawa N (2008) Proteomic analysis of the basic proteins in 5-fluorouracil resistance of human colon cancer cell line using the radical-free and highly reducing method of two-dimensional polyacrylamide gel electrophoresis. Int J Oncol 33:361-370

266. Wada A (1986) Analysis of Escherichia coli ribosomal proteins by an improved two dimensional gel electrophoresis II Characterization of four new proteins. J Biochem 100:1595-1605

267. Yang Y, Chen Z, Zhang G, Yi H, Xiao Z (2008) A Subcelluar Proteomic Investigation into Vincristine-Resistant Gastric Cancer Cell Line. J Cell Biochem 104:1010-1021

268. Liu Y, Liu H, Han B, Zhang J (2006) Identification of 14-3-3S as a contributor to drug resistance in human breast cancer cells using functional proteomic analysis. Cancer Res 66(6): $3248-3255$

269. Lim Y, Diong L, Qi R, Druker BJ, Epstein RJ (2003) Phosphoproteomic fingerprinting of epidermal growth factor signaling and anticancer drug action in human tumor cells. Mol Cancer Ther 2(12):1369-1377

270. Jiang Y, Sun Q, Fang X, Wang X (2009) Comparative mitochondrial proteomic analysis of Raji cells exposed to adriamycin. Mol Med 15(5-6):173-182

271. Zhang JT, Liu Y (2007) Use of comparative proteomics to identify potential resistance mechanisms in cancer treatment. Cancer Treat Rev 33:741-756

272. Allal AS, Kähne T, Reverdin AK, Lippert H, Schlegel W, Reymond M (2004) Radioresistance-related proteins in rectal cancer. Proteomics 4(8):2261-2269

273. Okano T, Kondo T, Fujii K, Nishimura T, Takano K, Ohe Y, Tsuta K, Matsuno Y, Gemma A, Kato H, Kudoh S, Hirohashi S (2007) Proteomic signature corresponding to the response to gefitinib (Iressa ZD1839) an epidermal growth factor receptor tyrosine kinase inhibitor in lung adenocarcinoma. Clin Cancer Res 13(3):799-805

274. Beranova-Giorgianni S (2003) Proteome analysis by twodimensional gel electrophoresis and mass spectrometry: strengths and limitations. Trends Anal Chem 22(5):273-281

275. Shi Y, Xiang R, Horvath C, Wilkins JA (2004) The role of liquid chromatography in proteomics. J Chromatogr A 1053:27-36

276. Neverova I, Van Eyk JE (2005) Role of chromatographic techniques in proteomic analysis. J Chromatogr B 815(1-2): 51-63

277. Wall DB, Kachman MT, Gong S, Hinderer R, Parus S, Misek DE, Hanash SM, Lubman DM (2000) Isoelectric focusing nonporous RP HPLC: a two-dimensional liquid-phase separation method for mapping of cellular proteins with identification using MALDI-TOF mass spectrometry. Anal Chem 72:1099-1111

278. Zurbriggen K, Schmugge M, Schmid M, Durka S, Kleinert P, Kuster T, Heizmann CW, Troxler H (2005) Analysis of minor hemoglobins by matrix-assisted laser desorption/ionization time-of-flight mass spectrometry. Clin Chem 51(6):989-996

279. Wu S, Tang X, Siems WF, Bruce JE (2005) A hybrid LC-GelMS method for proteomics research and its application to protease functional pathway mapping. J Chromatogr B 822(1-2):98-111

280. Ottens AK, Kobeissy FH, Wolper RA, Haskins WE (2005) A multidimensional differential proteomic platform using dualphase ion-exchange chromatography-polyacrylamide gel electrophoresis/reversed-phase liquid chromatography tandem mass spectrometry. Anal Chem 77:4836-4845

281. Opiteck GJ, Ramirez SM, Jorgenson JW, Moseley MA (1998) Comprehensive two-dimensional high-performance liquid chromatography for the isolation of overexpressed proteins and proteome mapping. Anal Biochem 258:349-361

282. Dauly C, Perlman DH, Costello CE, McComb ME (2006) Protein separation and characterization by np-RP-HPLC followed by intact MALDI-TOF mass spectrometry and peptide mass mapping analysis. J Proteome Res 5:1688-1700

283. Delahunty CM, Yates JR (2007) MudPIT: multidimensional protein identification technology. BioTechniques 43(5):563-569

284. Fujii K, Nakano T, Kawamura T, Usui F, Bando Y, Wang R, Nishimura $T$ (2004) Multidimensional protein profiling technology and its application to human plasma proteome. J Proteome Res 3:712-718

285. Jain KK (2004) Proteomics and drug discovery. Contrib Nephrol 141:308-327

286. Umar A, Kang H, Timmermans A, Look MP, Meijer-van Gelder ME, den Bakker MA, Jaitly N, Martens JWM, Luider TM, Foekens JA, Paša-Tolic L (2009) Identification of a putative protein profile associated with tamoxifen therapy resistance in breast cancer. Mol Cell Proteomics 8:1278-1294 
287. Zhang N, Li N, Li Liang (2004) Liquid chromatography MALDI MS/MS for membrane proteome analysis. J Proteome Res 3:719-727

288. Fung ET, Yip T, Lomas L, Wang Z, Yip C, Meng X, Lin S, Zhang F, Zhang Z, Chan DW, Weinberger SR (2005) Classification of cancer types by measuring variants of host response proteins using SELDI serum assays. Int J Cancer 115(5): 783-789

289. Schweigert FJ, Wirth K, Raila J (2004) Characterization of the microheterogeneity of transthyretin in plasma and urine using SELDI-TOF-MS immunoassay. Proteome Sci 2:5

290. Vlahou A, Schellhammer PF, Mendrinos S, Patel K, Kondylis FI, Gong L, Nasim S, Wright GL Jr (2001) Development of a Novel Proteomic Approach for the Detection of Transitional Cell Carcinoma of the Bladder in Urine. Am $\mathrm{J}$ Pathol 158(4):1491-1502

291. Albitar M, Potts SJ, Gilesc FJ, O’Briend S, Jilania I, Donahuea AC, Esteyd EH, Kantarjian H (2009) Proteomics-based prediction of clinical response in acute myeloid leukemia. Exp Hematol 37:784-790

292. Pusztai L, Phil D, Gregory BW, Baggerly KA, Peng B, Koomen J, Kuerer HM, Esteva FJ, Symmans WF, Wagner P, Hortobagyi GN, Laronga C, Semmes OJ, Wright GL Jr, Drake Vlahou RR (2004) A pharmacoproteomic analysis of prechemotherapy and postchemotherapy plasma samples from patients receiving neoadjuvant or adjuvant chemotherapy for breast carcinoma. Cancer 100(9): 1814-1822

293. Smith FM, Gallagher WM, Fox E, Stephens RB, Rexhepaj E, Petricoin EF, Liotta LA, Kennedy MJ, Reynolds JV (2007) Combination of SELDI-TOF-MS and data mining provides early-stage response prediction for rectal tumors undergoing multimodal neoadjuvant therapy. Ann Surg 245(2):259-266

294. Henzel WJ, Watanabe C, Stults JT (2003) Protein identification: the origins of peptide mass fingerprinting. Am Soc Mass Spectrom 14:931-942

295. Bienvenut WV, Déon C, Pasquarello C, Campbell JM, Sanchez J, Vestal MJ, Hochstrasser DM (2002) Matrix-assisted laser desorption/ionization-tandem mass spectrometry with high resolution and sensitivity for identification and characterization of proteins. Proteomics 2:868-876

296. Menzel C, Guillou V, Kellmann M, Khamenya V, Juergens M, Schulz-Knappe P (2005) High-throughput biomarker discovery and identification by mass spectrometry. Comb Chem High Throughput Screen 8:743-755

297. Steen JAJ, Stehen H, Georgi A, Parker K, Springer M, Kirchner M, Hamprecht F, Kirschner MW (2008) Different phosphorylation states of the anaphase promoting complex in response to antimitotic drugs: A quantitative proteomic analysis. Proc Natl Acad Sci USA 105(16):6069-6074

298. Umar A, Kang H, Timmermans AM, Look MP, Meijer-van Gelder ME, den Bakker MA, Jaitly N, Martens JWM, Luider TM, Foekens JA, Paša-Tolic L (2008) Identification of a putative protein profile associated with tamoxifen therapy resistance in breast cancer. Mol Cell Proteomics 8:1278-1294

299. Voortman J, Pham TV, Knol JC, Giaccone G, Jimenez CR (2009) Prediction of outcome of non-small cell lung cancer patients treated with chemotherapy and bortezomib by timecourse MALDI-TOF-MS serum peptide profiling. Proteome Sci $7: 34$

300. Tian Y, Tan A, Sun X, Olson MT, Xie Z, Jinawath N, Chan DW, Shih I, Zhang Z, Zhang H (2009) Quantitative proteomic analysis of ovarian cancer cells identified mitochondrial proteins associated with paclitaxel resistance. Proteomics Clin Appl 3(11):1288-1295

301. Mazouni C, Baggerly K, Hawke D, Tsavachidis S, André F, Buzdar AU, Martin PM, Kobayashi R, Pusztai L (2010)
Evaluation of changes in serum protein profiles during neoadjuvant chemotherapy in HER2-positive breast cancer using an LC-MALDI-TOF/MS procedure. Proteomics 10(19):3525-3532

302. Coons AH, Creech HJ, Jones RN (1941) Immunological Properties of an Antibody Containing a Fluorescent Group. Proc Soc Exp Biol Med 47:200-202

303. Gown AM (2008) Current issues in ER and HER2 testing by IHC in breast cancer. Mod Pathol 21:8-15

304. Nielsen TO, Hsu FD, Jensen K, Cheang M, Karaca G, Hu Z, Hernandez-Boussard T, Livasy C, Cowan D, Dressler L, Akslen LA, Ragaz J, Gown AM, Gilks CB, van de Rijn M, Perou CM (2004) Immunohistochemical and clinical characterization of the basal-like subtype of invasive breast carcinoma. Clin Cancer Res 10:5367-5374

305. Le Naour F, Misek DE, Krause MC, Deneux L, Giordano TJ, Scholl S, Hanash SM (2001) Proteomics-based identification of RS/DJ-1 as a novel circulating tumor antigen in breast cancer. Clin Cancer Res 7:3328-3335

306. Melle C, Ernst G, Schimmel B, Bleu A, Koscielny S, Wiesner A, Bogumil R, Moller U, Osterloh D, Halbhuber K, von Eggeling F (2004) Technical triade for proteomic identification and characterization of cancer biomarkers. Cancer Res 64:4099-4104

307. Steffensen KD, Waldstrøm M, Jeppesen U, Brandslund I, Jakobsen A (2008) Prediction of response to chemotherapy by ERCC1 immunohistochemistry and ERCC1 polymorphism in ovarian cancer. Int J Gynecol Cancer 18(4):702-710

308. Hewitt SM, Takikita M, Abedi-Ardekani B, Kris Y, Bexfield K, Braunschweig T, Chung J (2008) Validation of proteomic-based discovery with tissue microarrays. Proteomics Clin Appl 2:1460-1466

309. Ross JS, Symmans WF, Pusztai L (2005) Breast cancer biomarkers. Adv Clin Chem 40:99-125

310. Madoz-Gurpide J, Wang H, Misek DE, Brichory F, Hanash SM (2001) Protein based microarrays: a tool for probing the proteome of cancer cells and tissues. Proteomics 1:1279-1287

311. MacBeath G (2002) Protein microarrays and proteomics. Nature Genet Suppl 32:526-532

312. Liotta L, Petricoin EF (2000) Molecular profiling of human cancer. Nat Rev Genet 1:48-56

313. Zhu H, Snyder M (2003) Protein chip technology. Curr Opin Chem Biol 7:55-63

314. Angenendt P, Glökler J, Murphy D, Lehrach H, Dolores J (2002) Toward optimized antibody microarrays: a comparison of current microarray support materials. Anal Biochem 309(2): 253-260

315. Joos TO, Stoll D, Templin MF (2002) Miniaturised multiplexed immunoassays. Curr Opin Chem Biol 6(1):76-80

316. Espina V, Mehta AI, Winters ME, Calvert V, Wulfkuhle JD, Petricoin EF, Liotta LA (2003) Protein microarrays: molecular profiling technologies for clinical specimens. Proteomics 3:2091-2100

317. Haab BB (2005) Antibody arrays in cancer research. Mol Cell Proteomics 4:377-383

318. Chan SM, Ermann J, Su L, Fathman GC, Utz PJ (2004) Protein microarrays for multiplex analysis of signal transduction pathways. Nature Med 10(12):1390-1396

319. Jones RB, Gordus A, Krall JA, MacBeath G (2006) A quantitative protein interaction network for the ErbB receptors using protein microarrays. Nature 439(12):168-174

320. Nishizuka S, Charboneau L, Young L, Major S, Reinhold WC, Waltham M, Kouros-Mehr H, Bussey KJ, Lee JK, Espina V, Munson PJ, Petricoin EF, Liotta LA, Weinstein JN (2003) Proteomic profiling of the NCI-60 cancer cell lines using new high-density reverse-phase lysate microarrays. Proc Natl Acad Sci USA 100(24):14229-14234 
321. Ma Y, Ding Z, Qian Y, Shi X, Castranova V, Harner JE, Guo L (2006) Predicting cancer drug response by proteomic profiling. Clin Cancer Res 12(15):4583-4589

322. Bailey SN, Wu RZ, Sabatini DM (2002) Applications of transfected cell microarrays in high-throughput drug discovery Medical applications of microarray technologies: a regulatory science perspective. Nature Genet 32:474-479

323. Burbaum J, Toba GM (2002) Proteomics in drug discovery. Curr Opin Chem Biol 6(4):427-433

324. Boyd ZS, Wu QJ, O'Brien C, Spoerke J, Savage H, Fielder PJ, Amler L, Yan Y, Lackner MR (2008) Proteomic analysis of breast cancer molecular subtypes and biomarkers of response to targeted kinase inhibitors using reverse-phase protein microarrays. Mol Cancer Ther 7:3695-3706

325. Mirzoeva OK, Das D, Heiser LM, Bhattacharya S, Siwak D, Gendelman R, Bayani N, Wang NJ, Neve RM, Guan Y, Hu Z, Knight Z, Feiler HS, Gascard P, Parvin B, Spellman PT, Shokat KM, Wyrobek AJ, Bissell MJ, McCormick F, Kuo W, Mills GB, Gray JW, Korn WM (2009) Basal subtype and MAPK/ERK kinase (MEK)-phosphoinositide 3- kinase feedback signaling determine susceptibility of breast cancer cells to MEK inhibition. Cancer Res 69(2):565-572

326. Whitehead CM, Nelson R, Hudson P (2004) Selection and optimization of a panel of early stage breast cancer prognostic molecular markers. Mod Pathol 17:50A

327. Haab BB, Dunham MJ, ÓBrown P (2001) Protein microarrays for highly parallel detection and quantification of specific proteins and antibodies in complex solutions. Genome Biol 2(2):research00041-000413

328. Paweletz CP, Charboneau L, Bichsel VE, Simone NL, Chen T, Gillespie JW, Emmert-Buck MR, Roth MJ, Petricoin EF, Liotta LA (2001) Reverse phase protein microarrays which capture disease progression show activation of pro-survival pathways at the cancer invasion front. Oncogene 20:1981-1989
329. Cowherd SM, Espina VA, Petricoin EF, Liotta LA (2004) Proteomic analysis of human breast cancer tissue with laser-capture microdissection and reverse-phase protein microarrays. Clin Breast Cancer 5(5):385-392

330. Wang S, Yang H, Guo J, Liu M, Tong F, Cao Y, Zhou B, Liu P, Liu H, Cheng L, Xie F, Yang D, Zhang J (2011) Protein profiling predicts the response to anthracycline and taxanes based neo-adjuvant chemotherapy in breast cancer. BioChip J 5(1):32-38

331. Petricoin EF, Zoon KC, Kohn EC, Barrett JC, Liotta LA (2002) Clinical proteomics: translating benchside promise into bedside reality. Nat Rev Drug Discov 1:683-695

332. Eckel-Passow JE, Hoering A, Therneau TM, Ghobrial I (2005) Experimental design and analysis of antibody microarrays: applying methods from cDNA arrays. Cancer Res 65:2985-2989

333. Liotta LA, Espina V, Mehta AI, Calvert V, Rosenblatt K, Geho D, Munson PJ, Young L, Wulfkuhle JD, Petricoin EF (2003) Protein microarrays: meeting analytical challenges for clinical applications. Cancer Cell 3:317-325

334. Ferté C, André F, Soria JC (2010) Molecular circuits of solid tumors: prognostic and predictive tools for bedside use. Nat Rev Clin Oncol 7(7):367-380

335. Kulasingam V, Diamandis EP (2008) Strategies for discovering novel cancer biomarkers through utilization of emerging technologies. Nat Clin Pract Oncol 5(10):588-599

336. Spruessel A, Steimann G, Jung M, Lee SA, Carr T, Fentz AK, Spangenberg J, Zornig C, Juhl H, David KA (2004) Tissue ischemia time affects gene and protein expression patterns within minutes following surgical tumor. BioTechniques 36:1030-1032

337. Fentz AK, Spörl M, Spangenberg J, List HJ, Zornig C, Dörner A, Layer P, Juhl H, David KA (2007) Detection of colorectal adenoma and cancer based on transthyretin and C3a-desArg serum levels. Proteomics Clin Appl 1:536-544 